\title{
Green Design of a Cellulosic Butanol Supply Chain Network: A Case Study of Sorghum Stem Bio-butanol in Missouri
}

\author{
Li Liang and Henry J. Quesada*
}

Cellulosic butanol is a very promising renewable fuel to consider for the future transportation market. However, the seasonal availability of the raw materials, high maintenance cost, and high logistical cost of the biomass energy supply chain are the main factors impeding the commercialization and large-scale-production of this energy source. Furthermore, research focusing on an environmental or green supply chain network design of cellulosic butanol has been insufficient. This study focused on designing a green supply chain network for cellulosic butanol. A life cycle analysis was integrated into a multi-objective linear programming model to optimize the cellulosic butanol supply chain network. With the objectives of maximizing the economic profits and minimizing the greenhouse gas emissions, the proposed model can optimize the location and size of a bio-butanol production plant. The mathematical model was applied to a case study in the state of Missouri, and solved the tradeoff between the feedstock and market availabilities of sorghum stem bio-butanol.

Keywords: Cellulosic bio-butanol; Supply chain network design; MO-MILP; LCA; E-Constraint method

Contact information: Department of Sustainable Biomaterials, Virginia Tech, Brooks Center mail code 0503, Blacksburg, VA 24061, USA; *Corresponding author: quesada@vt.edu

\section{INTRODUCTION}

Renewable energy sources can reduce fossil fuel dependency and mitigate climate change (Cherubini and Strømman 2011), and as such they are an attractive option to ensure the security of future energy sources (Sharma et al. 2013). Among the various renewable energies, biomass energy is expected to play a dominant role in the future (Rentizelas et al. 2009). One of many biomass energies, cellulosic butanol, an alcoholic fuel that can be used as a direct replacement for gasoline, is a very promising renewable fuel in the future transportation market (Kumar and Gayen 2011). Because of its low water miscibility, similar energy content and octane number to that of gasoline, and blending ability with gasoline at any proportion, it can be directly utilized in gasoline engines (Kumar et al. 2009; Gu et al. 2012). However, the seasonal availability of the raw materials, high maintenance cost, and high logistical cost of the biomass energy supply chain are the main factors that impede the commercialization and large-scaleproduction of this energy source (Baños et al. 2011).

A good way to reduce these barriers is to utilize supply chain management. Supply chain management can effectively integrate the supply chain of a product by minimizing its relative cost (Eskandarpour et al. 2015). In supply chain management, the initial step is to design the supply chain network. The power of a well-designed supply chain network is remarkable, because it impacts all the subsequent decisions in the supply 
chain (Farahani et al. 2014). Supply chain network design (SCND) considers the number, location, and size of production plants and other associated facilities. The assignments between warehouses and retail outlets are also considered during SCND. Decision makers need to minimize the fixed and operation costs, while maximizing the economic profits. However, environmental issues are not sufficiently considered during this process (Elhedhli and Merrick 2012). Because of the quality revolution of the 1980s and supply chain revolution of the 1990s, it has become clear that the best supply chain management integrates environmental management with ongoing operations (Srivastava 2007). Green SCND, which combines the supply chain scope with environmental performance metrics at an early design stage (Miranda-Ackerman et al. 2017), is a good practice for integrating environmental management into SCND.

Green SCND is extension of traditional SCND. It requires the supply chain network to be designed in an environmental friendly way. In green SCND, economic profit is not the only factor to be considered. The carbon footprint, the waste generation, the energy use, and the material recovery, etc., are also important. Applying the green SCND into the commercialization of bio-butanol can achieve the environmental development of this energy resource without violating its economic performance. However, the current literature focused on the environmental or green SCND of biobutanol is insufficient. For example, Eskandarpour et al. (2015) reviewed 87 papers about sustainable SCND. Only six papers discussed the SCND of bio-ethanol (Mele et al. 2009; Corsano et al. 2011; You and Wang 2011; Akgul et al. 2012; Giarola et al. 2012; You et al. 2012), and none of the papers discussed bio-butanol SCND. For example, Giarola et al. (2012) generated a mixed-integer linear two-stage stochastic programming model in order to maximize the profits and minimize the GHG emissions of a multi-echelon and multi-period bioethanol supply chain network. In this network, the biomass cost and carbon cost are uncertain. In addition, Wang et al. (2011) developed a bi-objective mixed-integer optimization programming model and applied it in the green SCND of a global procurement center in a Chinese world-class company. In their model, the $\mathrm{CO}_{2}$ equivalent emissions is the only environmental metric used in the objective function. Finally, Mele et al. (2011) combined MODA with MILP and used it to optimize a sugarethanol supply chain. In this problem, the main conflict objectives are the environmental and economic performance of the entire supply chain.

Because of the advantages of using bio-butanol as an alternative energy supply, such as environmental protection, fuel performance, and transportation convenience, biobutanol has sufficient superiority over bioethanol. Therefore, the green SCND of cellulosic bio-butanol needs to be further researched.

This study focused on designing a green supply chain network for cellulosic biobutanol liquid fuel. In this research, a life cycle analysis (LCA) was used to develop a multi-objective linear programming (MOLP) model to optimize the cellulosic bio-butanol supply chain network. With this model, the optimal location and size of a bio-butanol production plant were selected with the objective of maximizing the economic profits and minimizing the environmental impacts. The mathematical model was applied to a case in the state of Missouri (MO). The optimal location and production capacity of a sorghum stem bio-butanol production plant were determined. To solve the MOLP model, the $\varepsilon$ constraint method was applied because of its applicability and simplicity. The $\mathcal{E}$ constraint method solved the MOLP model by changing the environmental objective function to be one of the constraints. 
The results of this research can be used to support the decision-making process at the strategic, tactical, and operational levels of cellulosic bio-butanol commercialization and cellulosic bio-butanol supply chain optimization. The results of this research can also be used as an introductory guideline for beginners who are interested in cellulosic biobutanol commercialization and supply chain design.

\section{LITERATURE REVIEW}

\section{Environmental Metrics for Green Supply Chain Network Design}

A traditional SCND model usually uses costs or profits as the target value in the mathematical model to measure the economic performance of a project (Autry et al. 2013). Similarly, a green SCND model also needs target values to measure the environmental performance and formulate a mathematical model. The metrics of measuring a green supply chain network help to select the environmental factors used by the green SCND model. According to a literature review of Ahi and Searcy (2015), at the end of 2012 there were 2,555 different metrics used in 445 articles related to green supply chain management and sustainable supply chain management. Although many of the metrics were only used once, there were a few commonly used metrics. Air emissions, greenhouse gas (GHG) emissions, energy use, and energy consumption were metrics used more than 20 times. For example, Elhedhli and Merrick (2012) developed a linear programming model for green SCND. In their model, the GHG emissions were used as an environmental performance measurement and embedded into the objective function. Comas Martí et al. (2015) used assignment-based formulation to design an environmental supply chain network. The model included not only the environmental impacts, but also the inventory level, demand uncertainty, transportation mode, and geographical differences of the procurement cost. In their model, the carbon emissions of each supply chain process were used as metrics to evaluate the environmental performance.

The carbon footprint, which is often quantified as GHG emissions, is a commonly-used to measure the environmental performance of a supply chain. The GHG emissions are defined as the total amount of GHG emitted from the supply chain (Eskandarpour et al. 2015). Theoretically, any type of GHG emission can be used to measure the total carbon footprint. However, for practical and economic reasons, carbon dioxide $\left(\mathrm{CO}_{2}\right)$ and methane $\left(\mathrm{CH}_{4}\right)$ are the most common indicators to measure the carbon footprint (Wright et al. 2011). Usually, GHG emissions do not need to be calculated explicitly, but can be estimated by the quantity of consumed energy (Harris et al. 2011) or by an economic input-output analysis from recent Error Input/Output (EIO) studies (Pourmohammadi et al. 2008). Additionally, there are many other commonly-used environmental metrics, such as the waste generated (Lira-Barragán et al. 2011; Pishvaee and Pazmi 2012; Eskandarpour et al. 2013), energy utility (Papapostolou et al. 2011; Corsano et al. 2011; Mohammadi et al. 2014), and material recovery (Minciardi et al. 2008; Harraz and Galal 2011; Amin and Zhang 2013).

\section{Models for Green Supply Chain Network Design}

In this SCND model, the main decision variables included the locations and sizes of the warehouses and production plants, technology selection, and transportation model selection. Because the flows within the supply chain network are usually modeled as continuous constraints, the formulation of a SCND model often includes mixed-integer 
mathematical models with single or multiple objective function (Eskandarpour et al. 2015). The single objective function model uses some conversion factors to convert the non-homogeneous measurements into a single objective function. For example, Zhang et al. (2017) proposed a mixed-integer nonlinear programing model to design a green supply chain network of an assembly manufacturing enterprise. The model used the unit $\mathrm{CO}_{2}$ emission tax as a conversion factor to convert the $\mathrm{CO}_{2}$ emission into the financial costs. Through this conversion, the model can use a single objective to minimize both economic cost and $\mathrm{CO}_{2}$ emission. The multi-objective model is used when the nonhomogeneous measurements are hard to convert into a single objective function. For example, Yeh and Chuang (2011) proposed a multi-objective mixed-integer non-linear programming model to select a partner for a green supply chain network. Their model had four conflicting objectives, which included product quality, time, cost, and green appraisal score. In this study, two multi-objective genetic algorithms were used to find the Pareto-optimal solutions and solve the conflicting objectives.

Objective models can be classified into deterministic and stochastic models (Eskandarpour et al. 2015). For example, Yue et al. (2014) proposed a multi-objective mixed-integer-linear-fractional programming model to address the network design problem of a sustainable cellulosic bioelectricity supply chain. In their large-scale model, the biomass supply system, preprocessing stage, conversion stage, and sale situation were considered. In some particular cases, a few factors, such as customer demand, transportation cost, waste generation, and emission generation, are not deterministic or known. In these cases, stochastic programming can be utilized. For example, Giarola et al. (2012) generated a mixed-integer linear two-stage stochastic programming model to maximize the profits and minimize the GHG emissions of a multi-echelon and multiperiod bioethanol supply chain network. In their network, the biomass and carbon costs were uncertain.

\section{Life Cycle Analysis}

An LCA refers to a quantitative environmental evaluation and assessment of the life cycle of a product (Rebitzer et al. 2004). The framework of an LCA includes the objective definition, inventory analysis, impact assessment, and interpretation, which are discussed in the following paragraphs. Figure 1 shows a summary of the relationship of these four elements in an LCA framework (ISO 14040 2006).

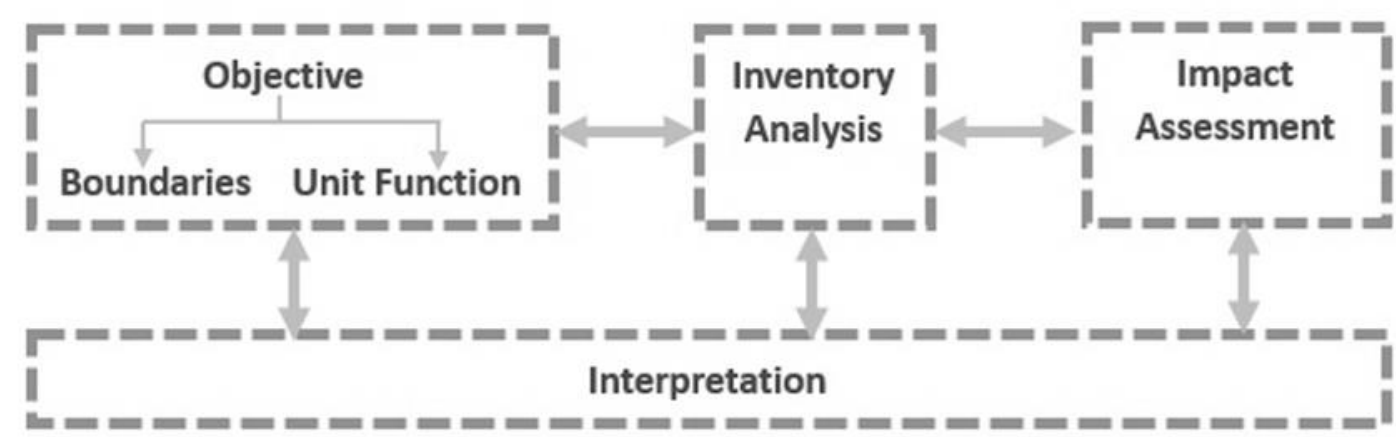

Fig. 1. Framework of an LCA

The first step of an LCA is to set up a well-defined objective for the study, and then the functional units and boundaries can be defined. The boundary can be classified into four types based on the different phases of a product: cradle-to-grave (from raw 
materials to disposal or recycling), cradle-to-gate (from raw materials to factory gate), gate-to-gate (manufacturing gate to delivery, transportation to another manufacturing gate, etc.), and gate-to-grave (from factory gate to disposal) (Eskandarpour et al. 2015). Functional units serve as reference units to measure the performance of a product system (ISO 14040 2006). Depending on the goal of the study, the functional unit must be represented in terms of per unit output. The functional unit can also be categorized into four types: input unit related, output unit related, unit agriculture land, and unit time (Cherubini and Strømman 2011). The core task of an inventory analysis is to collect and evaluate standardized data, as well as validate the pertinent data. After collecting the initial data, the system boundaries are decided by excluding the subsystems and material flows or by including the new unit processes. The data validation serves as a tool to improve the data quality (Jensen et al. 1998).

An impact assessment aims at expressing the output of the complex environmental analysis in terms of a few environmental impacts of interest. The environmental impacts of mid-point (theme) oriented life cycle impact assessment (LCIA) methods include the greenhouse effect, climate change, stratospheric ozone depletion, natural resource depletion, aquatic toxicity, human toxicity, eutrophication, acidification, etc. The environmental impacts of Endpoint (damage) oriented methods include human health-related, ecosystem health-related, and resource damages (Eskandarpour et al. 2015). In the mathematical model, both midpoint and endpoint methods can be used in an environmental assessment, and either an exhaustive LCA or partial LCA approach can be employed in the model (Eskandarpour et al. 2015).

The interpretation step analyzes the results provided by the inventory analysis and impact assessment, and conclusions and recommendations related to the scope and goal of the study are generated (Lo Giudice et al. 2014).

\section{Augmented $\varepsilon$-Constraint Method}

The $\varepsilon$-constraint method is used to optimize one of the objective functions by having other objectives serve as constraints. Equation 1 is the original optimization program and Eq. 2 is the transferred optimization program. Through this transformation, the original multi-objective problem can be transferred into a single objective problem. The right-hand side (RHS) of each constraint is determined by the payoff table. The payoff table shows the results coming from the individual optimization of each objective function, and these results can be obtained with a conventional linear programming (LP) optimizer (Mavrotas 2009).

$$
\begin{aligned}
& \operatorname{Max}\left(f_{1}(x), f_{2}(x), \ldots, f_{p}(x)\right) \\
& \text { st } \\
& \quad x \in S, \\
& \text { Max }\left(f_{1}(x)+e p s \times\left(s_{2}+s_{3}+\ldots+s_{p}\right)\right) \\
& \text { st } \\
& \quad f_{2}(x)-s_{2}=e_{2}, \\
& \quad f_{3}(x)-s_{3}=e_{3}, \\
& \quad \ldots \\
& \quad f_{p}(x)-s_{p}=e_{p}, \\
& \quad \mathrm{x} \in S \text { and } s_{i} \in R^{+},
\end{aligned}
$$


where $x$ is the vector of the decision variables, $f_{1}(x)$ to $f_{\mathrm{p}}(x)$ are the objective functions, $S$ is the feasible region, and $e_{1}$ to $e_{\mathrm{p}}$ are very small numbers (usually from $10^{-3}$ to $10^{-6}$ ).

The augmented $\varepsilon$-constraint method is an improvement of the original $\varepsilon$ constraint method, and it allows more accurate results than the original version (Mavrotas 2009). The new method is shown below as Eq. 3. In the augmented $\varepsilon$-constraint method, the payoff table is obtained by Lexicographic optimization, as shown in Table 1. For example, when optimizing $f_{1}(x)$ only, the optimal value of $f_{1}(x)$, which is $f_{1}\left(x_{1} *\right)$, can be obtained. Then, $f_{2}(x)$ can be optimized with the constraint that $f_{1}(x)$ equals $f_{1}\left(x_{1} *\right)$. These steps continue until the payoff table is completed. The range of each objective function is obtained from the payoff table, and $e_{\mathrm{i}}$ is obtained by dividing the range of the feasible solutions into even distributed intervals (Yu and Solvang 2016).

$$
\begin{aligned}
& \operatorname{Max} f_{1}(x) \\
& \text { st } \\
& f_{2}(x) \geq e_{2} \\
& f_{3}(x) \geq e_{3} \\
& \text {... } \\
& f_{p}(x) \geq e_{p} \\
& x \in S \text {, }
\end{aligned}
$$

where $S_{2}$ to $S_{\mathrm{p}}$ are the slack or surplus variables of each objective function.

Table 1. Example of a Payoff Table

\begin{tabular}{|c|c|c|c|c|}
\hline & $f_{1}(x)$ & $f_{2}(x)$ & $\ldots$ & $f_{\mathrm{p}}(x)$ \\
\hline $\operatorname{Max} f_{1}(x)$ & $f_{1}\left(x_{1}{ }^{*}\right)$ & $f_{2}\left(x_{1}{ }^{*}\right)$ & $\ldots$ & $f_{\mathrm{p}}\left(x_{1}{ }^{*}\right)$ \\
\hline $\operatorname{Max} f_{2}(x)$ & $f_{1}\left(x_{2}{ }^{*}\right)$ & $f_{2}\left(x_{2}{ }^{*}\right)$ & $\ldots$ & $f_{\mathrm{p}}\left(x_{2}{ }^{*}\right)$ \\
\hline$:$ & $:$ & $:$ & $\ldots$ & $:$ \\
\hline $\operatorname{Max} f_{\mathrm{p}}(x)$ & $f_{1}\left(x_{\mathrm{p}}{ }^{*}\right)$ & $f_{2}\left(x_{\mathrm{p}}{ }^{*}\right)$ & $\ldots$ & $f_{\mathrm{p}}\left(x_{\mathrm{p}}{ }^{*}\right)$ \\
\hline
\end{tabular}

In this research, a deterministic MOLP model was developed. In this model, two objective functions, environmental and economic, were used to maximize the global supply chain profits and minimize the GHG emissions. An LCA was used to evaluate the GHG emissions of each activity of the cellulosic bio-butanol supply chain, and the $\varepsilon$ constraint method was applied to deal with the tradeoff between the economic and environmental objectives in the MOLP model.

\section{PROBLEM STATEMENT}

The objectives of the model presented in this article are to maximize the economic profits and to minimize the GHG emissions of the sorghum bio-butanol supply chain. This was achieved by:

- Selecting the optimal location and capacity of the bio-butanol production plant,

- Determining the optimal bio-butanol transportation method. 
The problem to be addressed by the application of this model is shown in Fig. 2 . In this case, for a given sorghum stem bio-butanol supply chain network, the sorghum stem is the cellulosic biomass feedstock and bio-butanol is the major product. The local farmers or third-party feedstock aggregators are the feedstock suppliers, the bio-butanol production plant is the producer, and the fuel distribution centers are the customers. The suppliers deliver the sorghum stem to the producer by truck. Before being converted into bio-butanol, the feedstock is stored in warehouses on the production site. To be converted into bio-butanol, the sorghum stem needs to go through pretreatment, hydrolysis, fermentation, and bio-butanol recovery processes. The produced bio-butanol is stored in above-ground storage tanks (ASTs) before being delivered to the customers. The producer creates contracts with third party distribution companies to deliver the biobutanol to customers. The bio-butanol is shipped to the customers by railcars or oil-tanker trucks based on the distances between the producer and customers.

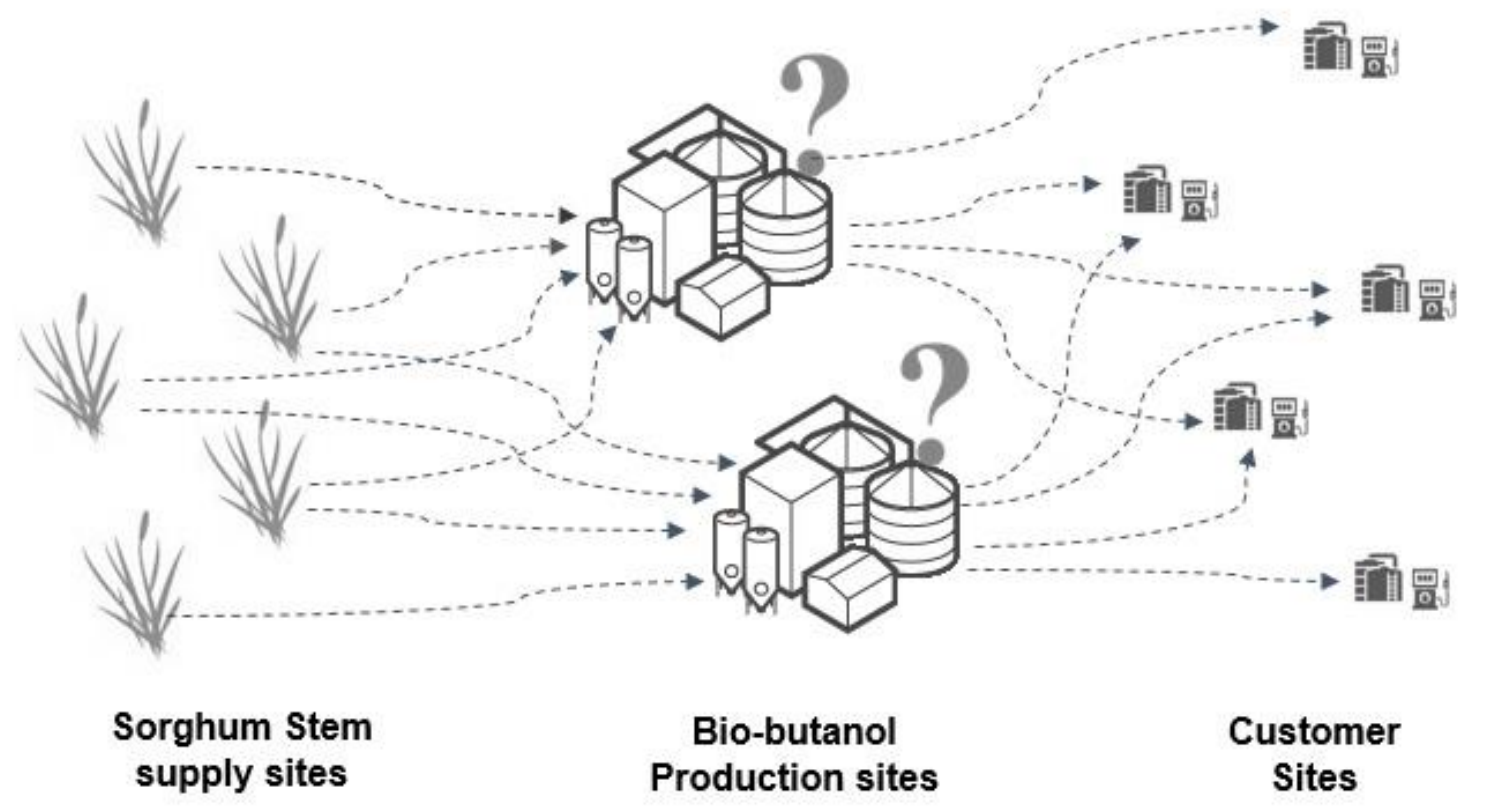

Fig. 2. Sorghum stem bio-butanol supply chain network

For the sorghum stem suppliers, the locations and associated annual maximum sorghum stem supply limit were given. The costs of harvesting and delivering one unit of sorghum stem for one mile were also known. The transportation distances between the suppliers and producers were obtained from online Google Maps (Google, Mountain View, CA, USA). Additionally, the GHG emissions from the sorghum stem harvest and transportation were obtained from SimaPro 8.2.3.0 (PRé Consultants B. V., Amersfoort, Netherlands). Given these parameters, the objective is to select the suppliers where the total cost (harvesting and delivering) is minimum. Positive continuous variables are used to select the best set of suppliers in order to meet the constraints and minimize total costs.

For the bio-butanol producer, the possible locations and bio-butanol yield from the sorghum stem were given. The capital cost of building a bio-butanol production plant with a certain capacity and bio-butanol production cost were also known. Additionally, the GHG emissions of the bio-butanol production were obtained from the LCA tool called GREET 2015 (U-Chicago Argonne LLC, Argonne, IL, USA). 
Table 2. Notation

\begin{tabular}{|c|c|}
\hline Nomenclature & Definition \\
\hline \multicolumn{2}{|r|}{ Sets } \\
\hline I & Set of sorghum stem suppliers, indexed by $i$ \\
\hline$J$ & Set of bio-butanol production plant candidates, indexed by $j$ \\
\hline K & Set of bio-butanol customers, indexed by $k$ \\
\hline$B$ & Sorghum stem feedstock, indexed by $B$ \\
\hline$F$ & Bio-butanol, indexed by $\mathrm{F}$ \\
\hline$L$ & Distributor, indexed by L \\
\hline \multicolumn{2}{|r|}{ Compound interest parameters } \\
\hline$P$ & The time period of the project, indexed by $p$ (year) \\
\hline$R$ & Discount Rate \\
\hline \multicolumn{2}{|r|}{ Demand parameter } \\
\hline$D_{\mathrm{k}}$ & The demand of customer $k$ \\
\hline \multicolumn{2}{|r|}{ Decision variables } \\
\hline$U_{\mathrm{Bi}}$ & The maximum harvest limit of sorghum stem $B$ from supplier $i(\mathrm{t})$ \\
\hline$x_{\mathrm{Bi}}$ & The amount of sorghum stem $B$ harvested from supplier $i(\mathrm{t})$ \\
\hline$X_{\mathrm{Bij}}$ & The amount of sorghum stem $B$ transported from supplier $i$ to producer $j(\mathrm{t})$ \\
\hline$x_{\mathrm{Fj}}$ & The amount of bio-butanol produced from production plant $j$ in time period $p(\mathrm{t})$ \\
\hline$X_{\mathrm{FUjk}}$ & The amount of bio-butanol transported from producer $j$ to customer $k$ by truck (t) \\
\hline$X \mathrm{FRjk}$ & $\begin{array}{l}\text { The amount of bio-butanol transported from producer } j \text { to customer } k \text { by railcar } \\
(\mathrm{t})\end{array}$ \\
\hline$X_{\mathrm{Fk}}$ & The amount of bio-butanol delivered to customer $k(t)$ \\
\hline$y_{j}$ & $\begin{array}{l}\text { Is } 1, \text { if the production plant } j \text { is open } \\
\text { Is } 0 \text {, otherwise }\end{array}$ \\
\hline$y \cup k$ & $\begin{array}{l}\text { Is } 1 \text {, if the bio-butanol is delivered from bio-refinery } j \text { to customer } k \text { by truck } \\
\text { Is } 0 \text {, otherwise }\end{array}$ \\
\hline$y_{\mathrm{Rk}}$ & $\begin{array}{l}\text { Is } 1 \text {, if the bio-butanol is delivered from bio-refinery } j \text { to customer } k \text { though } \\
\text { railway } \\
\text { Is } 0 \text {, otherwise }\end{array}$ \\
\hline \multicolumn{2}{|r|}{ Cumulated cash flows, costs, and emissions } \\
\hline$T_{\mathrm{ij}}$ & The amount of money exchanged between supplier $i$ and producer $j$ \\
\hline$T_{\mathrm{jL}}$ & The amount of money exchanged between producer $i$ and distributor $L$ \\
\hline $\mathrm{l}_{\mathrm{jk}}$ & The amount of money exchanged between producer $i$ and customer $k$ \\
\hline$\Pi_{\mathrm{i}}$ & The cash flow of supplier $i$ in each time period \\
\hline$\Pi_{\mathrm{j}}$ & The cash flow of producer $j$ in each time period \\
\hline$\Pi \mathrm{L}$ & The cash flow of distributor $L$ in each time period \\
\hline$\Pi_{\mathrm{k}}$ & The cash flow of customer $k$ in each time period \\
\hline$E_{\mathrm{B}}$ & The GHG emissions of cultivating and harvesting sorghum stem $B\left(\mathrm{~kg} \mathrm{CO}_{2} \mathrm{eq} / \mathrm{t}\right)$ \\
\hline Eтв & The $\mathrm{GHG}$ emissions of transporting sorghum stem $B\left(\mathrm{~kg} \mathrm{CO} 2 \mathrm{eq} / \mathrm{t}^{\star} \mathrm{mi}\right)$ \\
\hline ETUF & The GHG emissions of transporting bio-butanol $F$ by truck $\left(\mathrm{kg} \mathrm{CO}_{2} \mathrm{eq} / \mathrm{t}^{\star} \mathrm{mi}\right)$ \\
\hline ETRF & The GHG emissions of transporting bio-butanol $F$ by railcar $\left(\mathrm{kg} \mathrm{CO}_{2} \mathrm{eq} / \mathrm{t}^{*} \mathrm{mi}\right)$ \\
\hline$E_{\mathrm{F}}$ & The GHG emissions of producing bio-butanol $F(\mathrm{~kg} \mathrm{CO} 2 \mathrm{eq} / \mathrm{t})$ \\
\hline \multicolumn{2}{|r|}{ Production cost parameters } \\
\hline$C_{\mathrm{Bi}}$ & The unit cost of harvesting sorghum stem $B$ from producer $i(\$ / t)$ \\
\hline$C_{\text {TB }}$ & The unit cost of transporting sorghum stem $B\left(\$ / t^{\star} \mathrm{mi}\right)$ \\
\hline$C_{\text {TUF }}$ & The unit cost of transporting bio-butanol $F$ by truck $\left(\$ / t^{\star} \mathrm{mi}\right)$ \\
\hline$C_{\text {TRF }}$ & The unit cost of transporting bio-butanol $F$ by railway $\left(\$ / t^{\star} \mathrm{km}\right)$ \\
\hline$C_{\mathrm{j}}$ & The capital cost of building the bio-refinery $j(\$)$ \\
\hline$C_{\mathrm{Fj}}$ & The unit cost of producing $1 \mathrm{~kg}$ of bio-butanol $F$ from production plant $j(\$ / \mathrm{t})$ \\
\hline$C_{\mathrm{Fk}}$ & The selling price of bio-butanol $F$ to customer $k(\$ / t)$ \\
\hline$\lambda_{i j}$ & The transportation distance from harvesting site $i$ to bio-refinery $j(\mathrm{mi})$ \\
\hline$\lambda_{\mathrm{jk}}$ & The transportation distance from bio-refinery $j$ to distribution center $k(\mathrm{mi})$ \\
\hline$\alpha_{\mathrm{Bj}}$ & The bio-butanol $F$ yield from sorghum stem $B$ in bio-refinery $j(\mathrm{t} / \mathrm{t})$ \\
\hline
\end{tabular}


For the third-party distribution companies, the costs of delivering one unit of biobutanol by truck and railway for one mile were given. The transportation distances between the producers and customers were obtained from online Google Maps (Google). The GHG emissions of the bio-butanol delivered by truck and railcar were given by SimaPro 8.2.3.0. For each customer, the location, annual demand, and bio-butanol selling price were given. Binary variables ( 1 or 0$)$ or used to select the production sites and the delivery method (by truck or rail) based on total minimum costs.

\section{MATHEMATICAL MODEL}

\section{Environmental Objective Function}

The environmental objective function minimizes the GHG emissions of the feedstock cultivation and harvest, feedstock transportation, bio-butanol production, and bio-butanol transportation for the given time period, as shown by Eq. 4,

$$
\begin{aligned}
& \text { Min ei }=P \times\left(E_{\text {sorghum stem harvest }}+E_{\text {sorghum stem transportation }}+\right. \\
& \left.E_{\text {bio-butanol production }}+E_{\text {bio-butanol transportation }}\right)
\end{aligned}
$$

where $E_{\text {sorghum stem harvest }}$ is the GHG emissions from sorghum stem cultivation and harvest ( $\mathrm{kg} \mathrm{CO} 2 \mathrm{eq}), E_{\text {sorghum stem transportation }}$ is the $\mathrm{GHG}$ emissions from feedstock transportation $(\mathrm{kg} \mathrm{CO} 2 \mathrm{eq}), E_{\text {bio-butanol production }}$ is the $\mathrm{GHG}$ emissions from bio-butanol production $(\mathrm{kg}$ $\mathrm{CO}_{2} \mathrm{eq}$ ), and $E_{\text {bio-butanol transportation }}$ is the GHG emissions from bio-butanol transportation $(\mathrm{kg} \mathrm{CO} 2 \mathrm{eq})$.

The GHG emissions from sorghum stem harvest, feedstock transportation (from suppliers to producers), biofuel transportation (from producers to customers), and biobutanol production were calculated with Eqs. 5, 6, 7, and 8, respectively:

$$
\begin{aligned}
& E_{\text {sorghum stem harvest }}=E_{B} \times \sum_{i=i}^{I} x_{B i} \\
& E_{\text {sorghum stem transportation }}=E_{T B} \sum_{i=i}^{I} \sum_{j=i}^{J} x_{B i j} \lambda_{i j} y_{j} \\
& E_{\text {bio-butanol transportation }}=E_{T U F} \sum_{k=1}^{K} \sum_{j=1}^{J} x_{F U j k} \lambda_{j k} y_{j} y_{U K}+E_{T R F} \sum_{k=1}^{K} \sum_{j=1}^{J} x_{F R j k} \lambda_{j k} y_{j} y_{R K} \\
& E_{\text {bio-butanol production }}=E_{F} \sum_{j=1}^{J} x_{F j} \times y_{j}
\end{aligned}
$$

\section{Economic Objective Function}

The economic objective function is shown by the following equation:

$$
\begin{aligned}
& \text { Max ec }=\sum_{p=1}^{P} \frac{1}{(1+R)^{p}} \times\left(C_{\text {bio-butanol selling }}-C_{\text {sorghum stem harvest }}-\right. \\
& \left.C_{\text {sorghum stem transportation }}-C_{\text {bio-butanol production }}-C_{\text {bio-butanol transportation }}\right) \\
& -C_{\text {production plant set up }}
\end{aligned}
$$


where $C_{\text {bio-butanol selling }}$ is the earnings of selling the bio-butanol $(\$), C_{\text {sorghum stem harvest }}$ is the

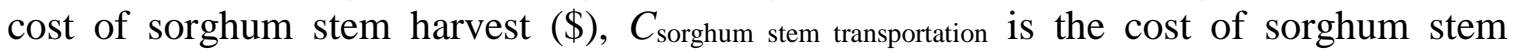
transportation (\$), $C_{\text {bio-butanol production }}$ is the cost of bio-butanol production (\$), $C_{\text {bio-butanol }}$

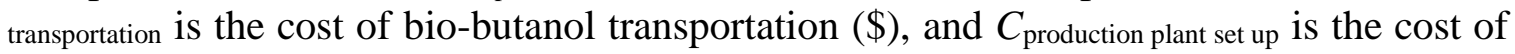
building a bio-butanol production plant (\$).

The earnings of selling the bio-butanol were calculated with Eq. 10:

$$
C_{b i o-b u \tan o l \text { selling }}=\sum_{k=1}^{K} C_{F k} \boldsymbol{x}_{F k}
$$

The costs of the sorghum stem harvest, sorghum stem transportation, bio-butanol production, building a bio-butanol production plant, and bio-butanol transportation were calculated with Eqs. 11, 12, 13, 14, and 15, respectively:

$$
\begin{aligned}
& C_{\text {sorghum stem harvest }}=\sum_{i=1}^{I} C_{B i} x_{B i} \\
& C_{\text {sorghum stem transportation }}=C_{T B} \sum_{i=1}^{I} \sum_{j=1}^{J} x_{B i j} \lambda_{i j} y_{j} \\
& C_{\text {bio-butanol production }}=\sum_{j=1}^{J} C_{F j} x_{F j} y_{j} \\
& C_{\text {production plant set up }}=\sum_{j=1}^{J} C_{j} y_{j} \\
& C_{\text {bio-butanol transportation }}=C_{T U F} \sum_{k=1}^{K} \sum_{j=1}^{J} x_{F U j k} \lambda_{j k} y_{j} y_{U K}+C_{T R F} \sum_{k=1}^{K} \sum_{j=1}^{J} x_{F R j k} \lambda_{j k} y_{j} y_{R K}
\end{aligned}
$$

The proof of the economic objective function is shown below.

The cash flow of each time period for each supplier is the earnings from selling the sorghum stem minus the sum of the biomass harvest and biomass delivery costs:

$$
\Pi_{i}=\sum_{j=1}^{J} T_{i j} y_{j}-C_{B i} x_{B i}-C_{T B} \sum_{j=1}^{J} x_{B i j} \lambda_{i j} y_{j} \quad \forall i \in I
$$

The cash flow of each time period for each producer candidate is the selling of the cellulosic bio-butanol minus the sum of the bio-butanol production, third party logistical contract, and biomass purchased costs:

$$
\Pi_{j}=y_{j}\left(\sum_{k=1}^{K} T_{j k}-\sum_{i=1}^{I} T_{i j}-C_{F j} x_{F j}-T_{j L}\right) \quad \forall j \in J
$$

The cash flow of each time period for the distributor is the earnings from the contract with the producer minus the cost of bio-butanol delivery:

$$
\Pi_{L}=\sum_{j=i}^{J} T_{j L} y_{j}-C_{T U F} \sum_{j=1}^{J} \sum_{k=1}^{K} x_{F U j k} \lambda_{j k} y_{j} y_{U k}-C_{T R F} \sum_{j=1}^{J} \sum_{k=1}^{K} x_{F R j k} \lambda_{j k} y_{j} y_{R k}
$$

The cash flow of each time period for each customer is the selling of the biobutanol minus the cost of bio-butanol purchased: 


$$
\prod_{k}=C_{F k} x_{F k}-\sum_{j=1}^{J} T_{j k} y_{j} \quad \forall k \in K
$$

Therefore, the economic objective function is given, as follows:

$$
\begin{aligned}
& e c=\sum_{p=1}^{P} \frac{1}{(1+R)^{P}} \\
& \quad-\left(C_{\text {bio-butanl selling }}-C_{\text {sorghum stem harvest }}-C_{\text {sorhum stem transportation }}\right. \\
& \quad-C_{\text {bio-butanl production }}-C_{\text {bio-butanl transportation })-C_{\text {production plant set up }}} \\
& e c=\sum_{p=1}^{P} \frac{1}{(1+R)^{P}}\left(\sum_{i=1}^{I} \Pi_{i}+\sum_{j=1}^{J} \Pi_{j}+\Pi_{L}+\sum_{k=1}^{K} \Pi_{k}\right)-C_{\text {production plant set up }}
\end{aligned}
$$

\section{Constraints}

The amount of sorghum stem harvested from supplier $i$ should not exceed the maximum harvesting limit of the supplier:

$$
x_{B i} \leq u_{B i} \quad \forall i \in I
$$

The total amount of sorghum stem delivered to different bio-refineries from supplier $i$ should be equal to the amount of feedstock harvested from supplier $i$ :

$$
\sum_{j=1}^{J} x_{B i j} y_{j}=x_{B i} \quad \forall i \in I
$$

The amount of sorghum stem in each bio-refinery $j$ should be:

$$
\sum_{i=1}^{I} x_{B i j}=x_{B j} \quad \forall j \in J
$$

The amount of bio-butanol produced in bio-refinery $j$ is obtained by multiplying the amount of sorghum stem in bio-refinery $j$ with the conversion rate:

$$
\alpha_{B j} \boldsymbol{x}_{B j}=\boldsymbol{x}_{F j} \quad \forall j \in J
$$

The amount of bio-butanol delivered from bio-refinery $j$ to different customers should not exceed the amount of bio-butanol produced at bio-refinery $j$ :

$$
\sum_{k=1}^{K} \boldsymbol{x}_{F U j k} y_{U k}+\sum_{k=1}^{K} \boldsymbol{x}_{F R j k} y_{R k} \leq \boldsymbol{x}_{F j} \quad \forall j \in J
$$

The amount of bio-butanol delivered to each customer $k$ should be:

$$
\sum_{j=1}^{J} x_{F U j k} y_{U k} y_{j}+\sum_{j=1}^{J} x_{F R j k} y_{R k} y_{j}=x_{F k} \quad \forall k \in K
$$

The amount of bio-butanol delivered from bio-refinery $j$ to each customer $k$ should not exceed the demand of customer $k$ :

$$
D_{k} \geq x_{F k} \quad \forall k \in K
$$


A binary variable was introduced to select the location of the bio-refineries:

$y_{j} \leq 1, y_{j} \in N^{+} \quad \forall j \in J$

A binary variable was introduced to select the bio-butanol transportation method:

$$
y_{U k} \leq 1, y_{U k} \in N^{+} \quad \forall k \in K
$$

\section{IMPLEMENTATION OF THE MULTI-OBJECTIVE LINEAR PROGRAMMING (MOLP) MODEL: A CASE STUDY IN MISSOURI (MO)}

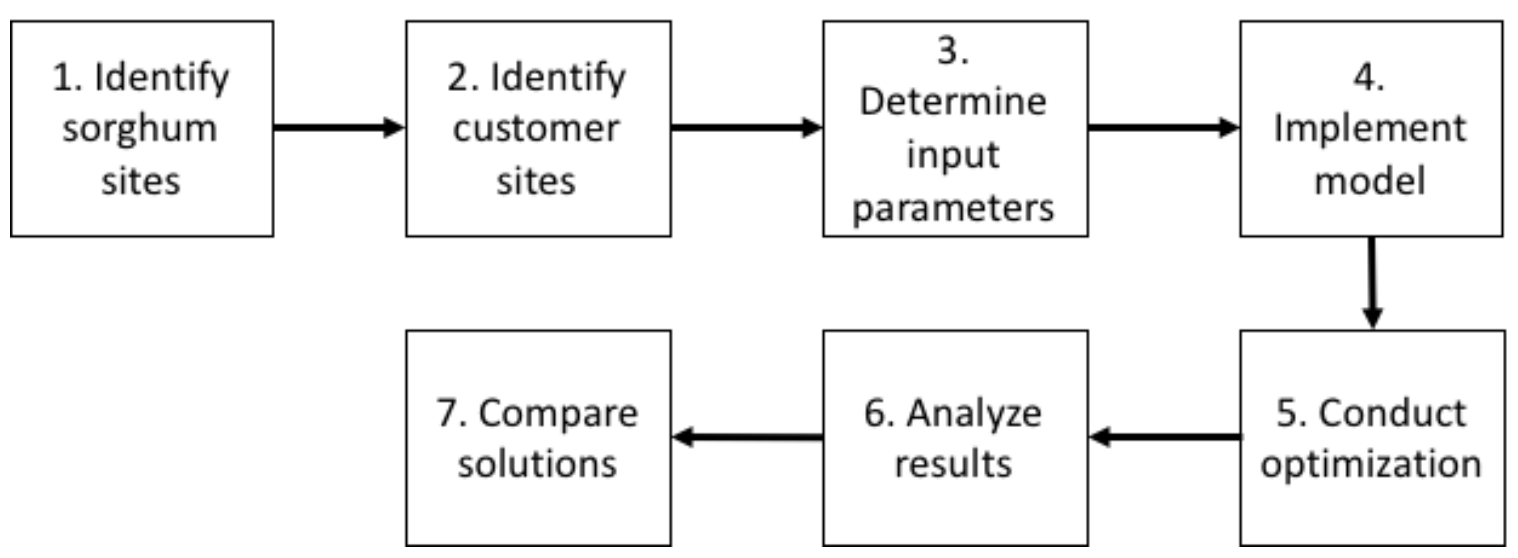

Fig. 3. A flowchart showing the implementation of the mathematical model.

The steps to conduct the implementation of the mathematical model are shown in Fig. 3. The first step in order to implement the mathematical model was to identify a suitable location. In this case, the funding agency supporting the project required that the model was implemented in the state of Missouri (MO). Following, potential sites for customers (distribution centers) were also located. The next step required the determination of the input parameters to conduct the implementation of the model. Finally, results were analyzed and compared with different scenarios.

The potential sorghum production sites and fuel distributors were identified based on production of sorghum and potential market. According to the national agriculture statistic service (USDA 2015a), MO has a total of 155,000 ac of planted sorghum (Table 3 ) and there are 88,900 ac of planted sorghum farmland in southeast MO, which contains $57.35 \%$ of the total sorghum planted farmland in MO. Therefore, compared with the other regions in $\mathrm{MO}$, the southeast region of $\mathrm{MO}$ was a better location to source the feedstock for the sorghum stem bio-butanol supply chain.

Table 3. Sorghum Farm Distribution in MO by Region (USDA 2015a)

\begin{tabular}{|c|c|c|}
\hline Region in MO & Area Planted (ac) & Percentage \\
\hline Northeast & 6,900 & $4.45 \%$ \\
\hline Central & 9,500 & $6.13 \%$ \\
\hline Southwest & 3,600 & $2.32 \%$ \\
\hline South Central & 3,500 & $2.26 \%$ \\
\hline Southeast & 88,900 & $57.35 \%$ \\
\hline Other Districts & 42,600 & $27.48 \%$ \\
\hline Missouri & 155,000 & $100 \%$ \\
\hline
\end{tabular}


However, fewer potential customers (fuel distributors) can be found in southeast MO. Major fuel distributors are located in the central region of MO. Figure 4 was created through a map tool called ZeeMap (Zee Source, Cupertino, CA, USA). According to this map, many fuel distributors are centralized around the city of St. Louis. There are only a few customers located around southeast MO.

In the central region of MO, there are less sorghum stem producers, but there is a larger market potential. While the southeastern region of MO has more sorghum stem producers, the region has a smaller potential market. A tradeoff exists between the feedstock and market availabilities. Therefore, in this case study, two scenarios were used to compare the priority between the feedstock and market availabilities. In the first scenario, the bio-refinery was located in the central region of MO, while in the second scenario, the bio-refinery was located in the southeast part of MO. In each scenario, a potential location for a bio-butanol production plant, locations of a few possible suppliers, and locations of possible customers were given. The model was applied to both scenarios, and the optimal solutions of each scenario were compared to select the optimal location of a sorghum stem bio-butanol production plant in MO.
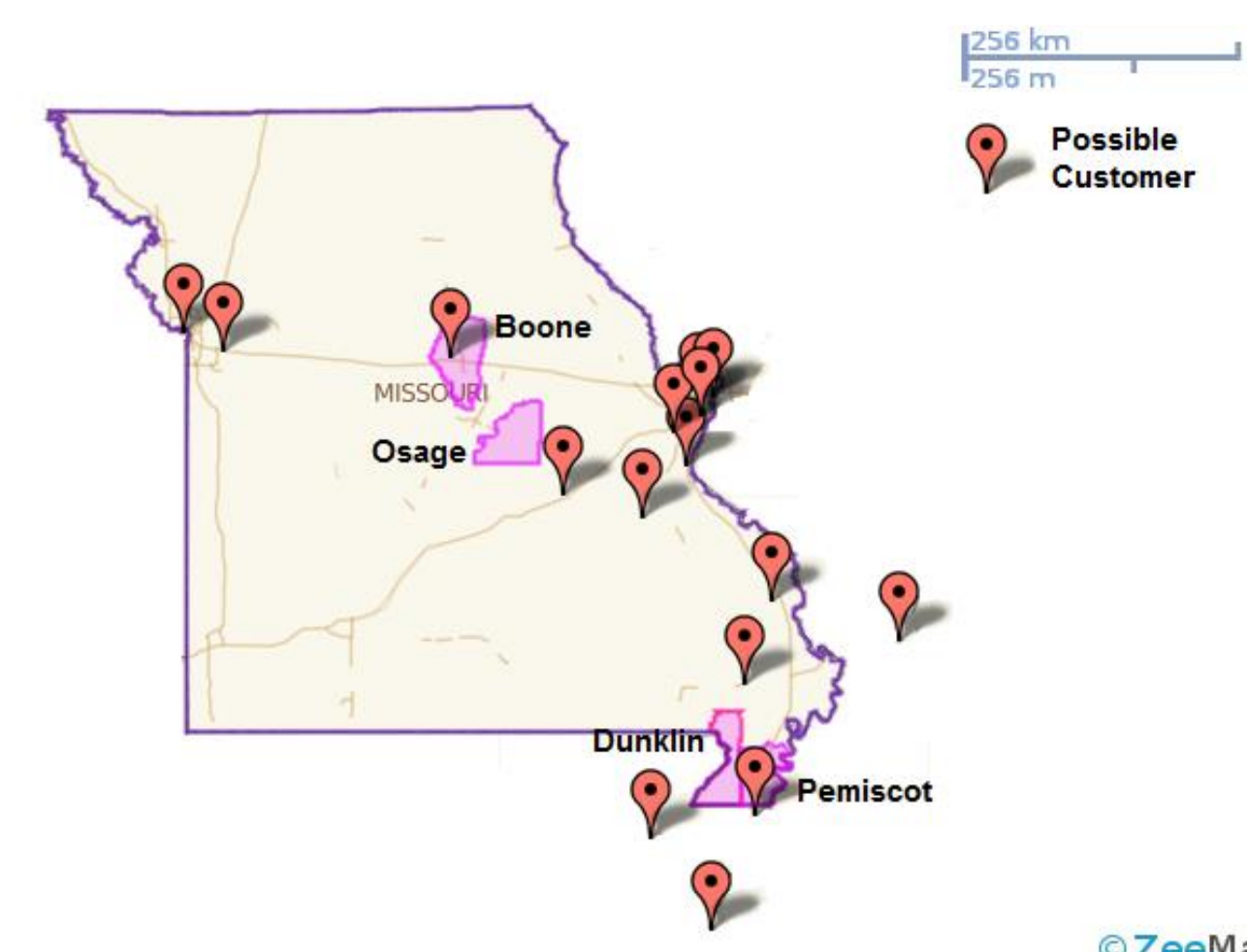

\section{Possible Customer}

Fig. 4. Fuel distributors near the major sorghums supply counties

\section{Scenario 1: Central MO}

In this scenario, three counties, Callaway, Boone, and Osage, were selected as the suppliers because of their larger sorghum planted areas. The sorghum planted area of each selected county is given in Table 4. The planted area of each county was obtained from the NASS data for 2014 (USDA 2015a), and the sorghum stem production was calculated with a sorghum stem yield of 21.5 t/ac (Almodares et al. 2008). 
Table 4. Related Information of the Selected Suppliers in Central MO

\begin{tabular}{|c|c|c|}
\hline County Name & Area Planted (ac) & Sorghum Stem Production $(\mathrm{t})$ \\
\hline Callaway & 1,700 & 36,550 \\
\hline Boone & 2,000 & 43,000 \\
\hline Osage & 1,200 & 25,800 \\
\hline
\end{tabular}

To lower the feedstock transportation cost, the geographical middle point of these three counties was selected as the location of the bio-butanol production plant. Therefore, the bio-butanol production plant in central MO was in Callaway County, as can be seen in Fig. 5. In Figure 5, the boundary of MO is highlighted in purple, and the three selected suppliers are highlighted in pink. Because the biomass feedstock has a transportation distance limit of $30 \mathrm{mi}$, a blue circle was used to represent the 30-mi-radius limit of the feedstock transportation. Because all of the suppliers were covered or almost covered by the blue circle, a worst-case scenario was used to calculate the distances between the producer and suppliers. There were eight possible customers in the central region. The demand of each customer and travel distances between the producer and customers are given in Table 5.

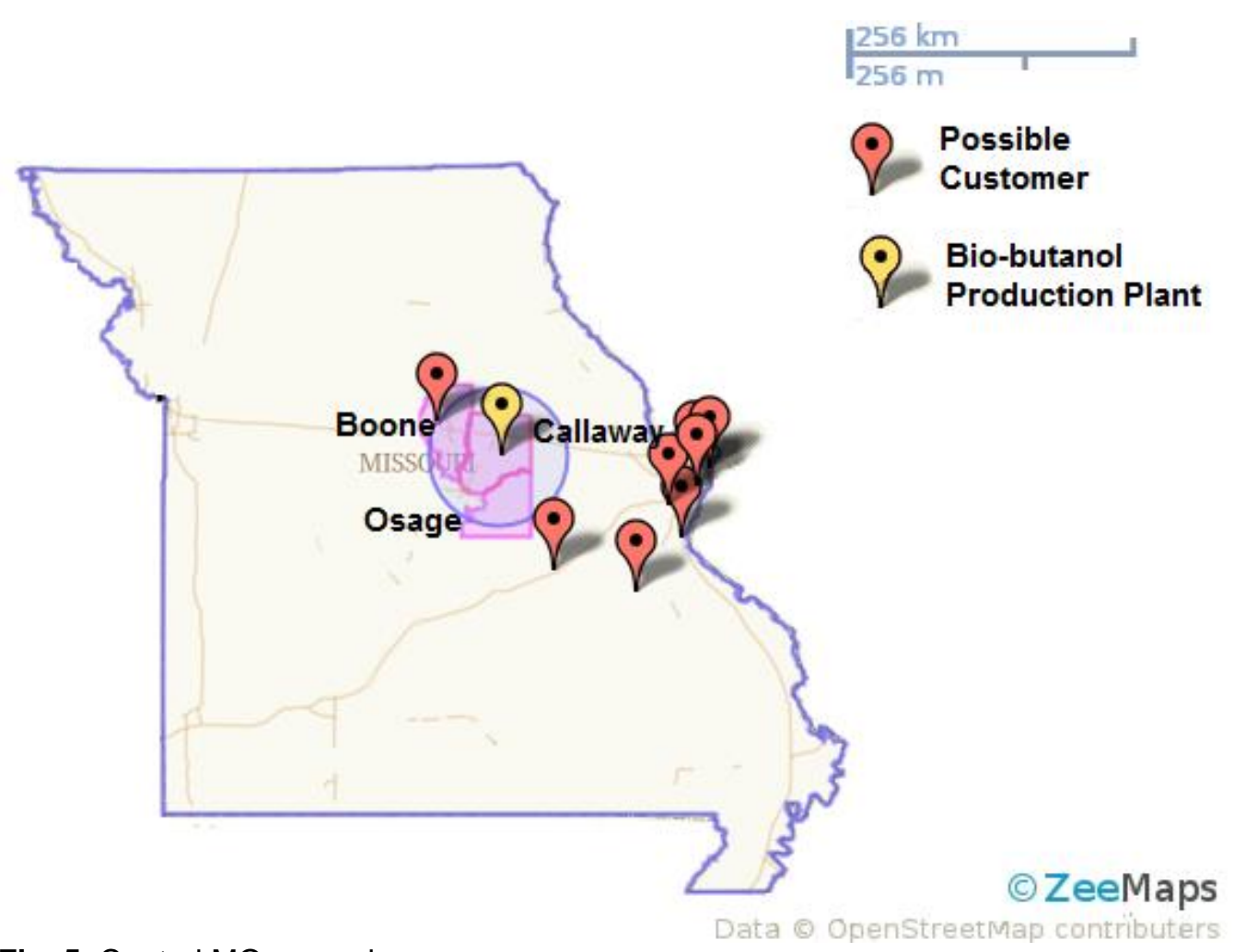

Fig. 5. Central MO scenario

Table 5. Information of Each Customer in Central MO

\begin{tabular}{|c|c|c|c|c|c|c|c|c|}
\hline Customer & 1 & 2 & 3 & 4 & 5 & 6 & 7 & 8 \\
\hline Distance (mi) & 36.66 & 82.64 & 110.6 & 111.85 & 126.76 & 108.74 & 104.39 & 113.09 \\
\hline Demand (thousand t) & 1,000 & 800 & 1,500 & 1,000 & 1,300 & 1,500 & 2,000 & 2,000 \\
\hline
\end{tabular}




\section{Scenario 2: Southeastern MO}

In this scenario, Dunklin, Pemiscot, and New Madrid, were selected as the suppliers because of their larger sorghum planted areas. The sorghum planted area of each selected county are given in Table 6 . The planted area of each county was obtained from the NASS data for 2014 (USDA 2015a), and the sorghum stem production was calculated with a sorghum stem yield of $21.5 \mathrm{t} / \mathrm{ac}$ (Almodares et al. 2008).

Table 6. Related Information of the Selected Suppliers in Southeastern MO

\begin{tabular}{|c|c|c|}
\hline County Name & Area Planted (ac) & Sorghum Stem Production $(\mathrm{t})$ \\
\hline Dunklin & 4,000 & 86,000 \\
\hline Pemiscot & 3,700 & 79,550 \\
\hline New Madrid & 2,200 & 47,300 \\
\hline
\end{tabular}

To lower the feedstock transportation cost, the geographical middle point of these three counties was selected as the location of the bio-butanol production plant. Therefore, the bio-butanol production plant in the southeastern MO was in New Madrid County, as indicated in Fig. 6. In Figure 6, the boundary of MO is highlighted in purple, and the three selected suppliers are highlighted in pink. The blue circle is the possible sourcing area. Because all of the suppliers were covered or almost covered by the blue circle, the distances between the producers and suppliers were assumed to be $30 \mathrm{mi}$. Additionally, there were eight possible customers in the southeastern region. The demand of each customer and travel distances between the producer and customers are given in Table 7.

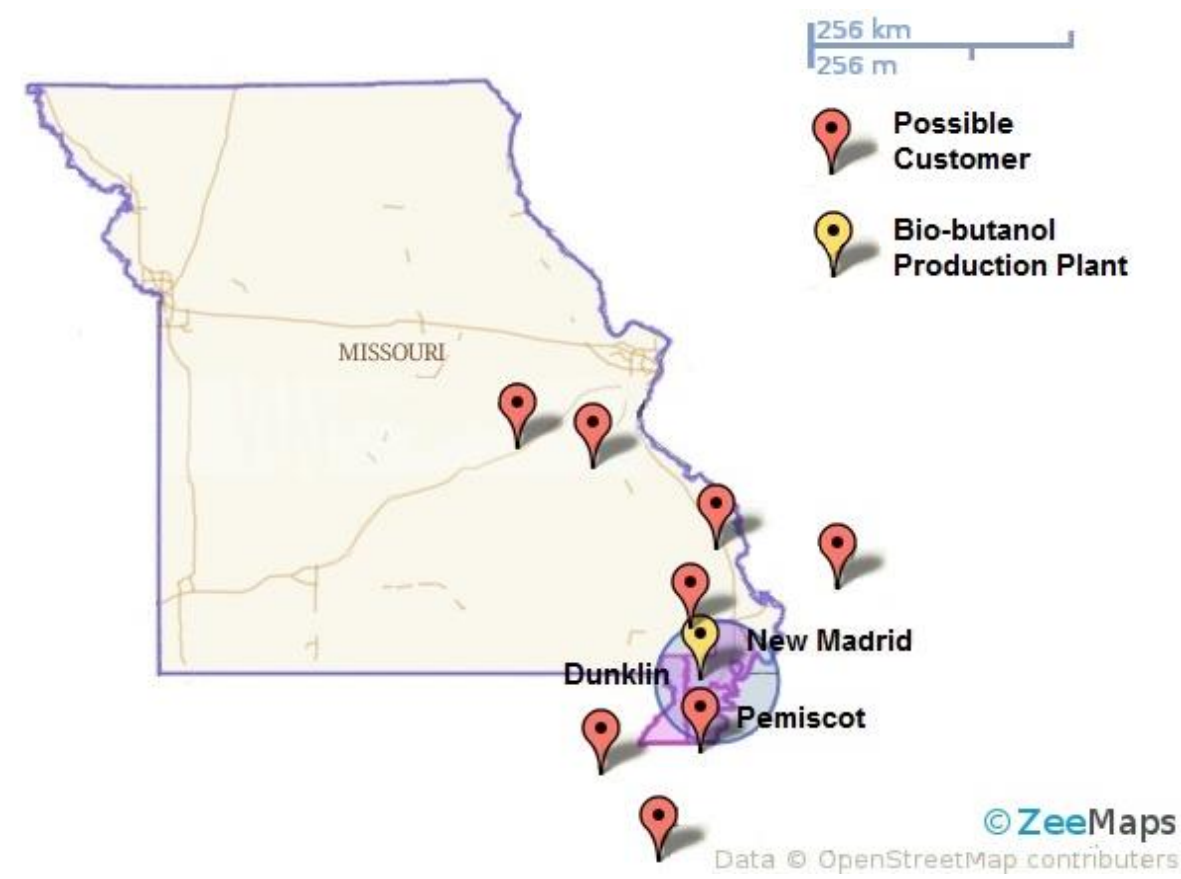

Fig. 6. Southeastern MO scenario

Table 7. Information of Each Customer in Southeastern MO

\begin{tabular}{|c|c|c|c|c|c|c|c|c|}
\hline Customer & 1 & 2 & 3 & 4 & 5 & 6 & 7 & 8 \\
\hline Distance (mi) & 77.67 & 36.66 & 99.42 & 85.75 & 46.6 & 105.63 & 155.34 & 153.48 \\
\hline Demand (thousand t) & 1,800 & 2,000 & 1,000 & 1,200 & 800 & 1,000 & 1,500 & 1,300 \\
\hline
\end{tabular}




\section{Input Parameters}

To integrate the LCA into the mathematical model, the GHG emissions were used as the environmental impact indicator. To simplify the calculation, most of the GHG emissions were aggregated into one single indicator called $\mathrm{CO}_{2}$ equivalent emissions with the method PICC 2007 GWP 100a V1.02 in SimaPro 8.2.3.0. However, because the data of the iso-butanol production was gathered from GREET 2015, the calculation method was different from that used in SimaPro. The GHG emissions could not be aggregated into the $\mathrm{CO}_{2}$ equivalent indicator, so the GHG emissions from iso-butanol production were represented by the total GHG emissions. Table 8 shows the LCA input parameters and Table 9 shows the input parameters in the mathematical model.

Table 8. LCA Input Parameters

\begin{tabular}{|c|c|}
\hline Parameter & Value \\
\hline$E_{\mathrm{B}}$ & $0.0325 \mathrm{~kg} \mathrm{CO} 2 \mathrm{eq} / \mathrm{kg}$ \\
\hline$E_{\mathrm{TB}}$ & $0.000631 \mathrm{~kg} \mathrm{CO} 2 \mathrm{eq} /\left(\mathrm{kg}^{*} \mathrm{mi}\right)$ \\
\hline$E_{\mathrm{F}}$ & $2.68 \mathrm{~kg} \mathrm{GHG} / \mathrm{kg}$ \\
\hline$E_{\mathrm{TUF}}$ & $1.18 \mathrm{E}-4 \mathrm{~kg} \mathrm{CO} 2 \mathrm{eq} /\left(\mathrm{kg}^{*} \mathrm{mi}\right)$ \\
\hline$E_{\mathrm{TRF}}$ & $3.54 \mathrm{E}-5 \mathrm{~kg} \mathrm{CO} \mathrm{eq}_{2} /\left(\mathrm{kg}^{*} \mathrm{mi}\right)$ \\
\hline
\end{tabular}

Table 9. Values of the Other Input Parameters

\begin{tabular}{|c|c|c|}
\hline Parameter & Value & Reference \\
\hline$U_{\mathrm{Bi}}$ & Tables 3 and 4 & USDA (2015a) \\
\hline$C_{B i}$ & $\$ 34.5 / \mathrm{ton}$ or $\$ 0.038 / \mathrm{kg}$ & \multirow{2}{*}{ U.S. EPA (2010) } \\
\hline$C_{\text {TB }}$ & $\$ 6.14 /$ ton $+0.64 /$ ton* $n^{*}$ or & \\
\hline$C_{\text {TUF }}$ & $\$ 0.0068 / \mathrm{kg}+0.0007 / \mathrm{kg}^{*} \mathrm{mi}$ & Searcy et al. (2007) \\
\hline$C_{\text {TRF }}$ & $\$ 0.06 /$ ton ${ }^{*} \mathrm{~km}$ or $\$ 0.00009 / \mathrm{kg}^{*} \mathrm{mi}$ & The World Bank (2011) \\
\hline$C_{\mathrm{j}}$ & $\$ 0.03 / \mathrm{ton}^{*} \mathrm{~km}$ or $\$ 0.00005 / \mathrm{kg}^{*} \mathrm{mi}$ & Dutton (2017) \\
\hline$C_{\mathrm{Fj}}$ & $\$ 140,930,000$ & Zhang et al. (2011) \\
\hline$\alpha_{\mathrm{Bj}}$ & $\$ 0.72 / \mathrm{kg}$ & U.S. EPA (2010) \\
\hline$\lambda_{\mathrm{ij}}$ & $8.5 \mathrm{~g} / \mathrm{L}$ & \\
\hline
\end{tabular}

\section{General Assumptions}

To better understand the tradeoff between the feedstock and market availabilities, some irrelevant variables needed to be controlled. Therefore, for both scenarios, it was assumed that:

- the time period of this project was 5 years and a discount rate of $10 \%$. Both were arbitrarily chosen

- the unit sorghum stem harvest cost was the same for all of the suppliers

- the unit sorghum stem transportation cost was the same

- the transportation distance between the suppliers and producer was $30 \mathrm{mi}$

- the bio-butanol selling price was $\$ 3.00 /$ gal for all of the customers

- both bio-butanol transportation methods were acceptable for all of the customers

- the conversion rate of bio-butanol was the same for all of the producers

When applying the $\varepsilon$-constraint method, 600 grid points were used to divide the feasible range of the model. 


\section{RESULTS AND DISCUSSION}

\section{Results for the Central MO Scenario}

In the first scenario, the limitation of the feedstock availability did not allow the producer to serve all eight possible customers. Customer 5, which was $126.76 \mathrm{mi}$ away from the producer, could not be served. As such, instead of having eight customers, the producer in central MO only had seven customers. The optimal bio-butanol transportation method was by railcar because of its low delivery costs and GHG emissions. The maximum profits for five years were $\$ 3,050$ million, with total GHG emissions of 116.56 million $\mathrm{t}$ of $\mathrm{CO}_{2}$ eq over five years and an annual production size of 9,577 thousand $\mathrm{t}$ of bio-butanol. The minimum GHG emission was $0 \mathrm{t}$ of $\mathrm{CO}_{2}$ eq with a profit of $\$ 0$. The $\mathcal{E}$ constraint method was used to solve the multi-objective model. The relationship between the economic and environmental objectives was positive-linear, as shown in Fig. 7. If the GHG emissions decreased by 194 thousand $\mathrm{t}$ of $\mathrm{CO}_{2}$ eq, the total profits of the biobutanol supply chain decreased by $\$ 5.3$ million. Essentially, to reduce the GHG emissions by $1 \mathrm{t}$ of $\mathrm{CO}_{2} \mathrm{eq}$, the producer needed to pay $\$ 27.20$.

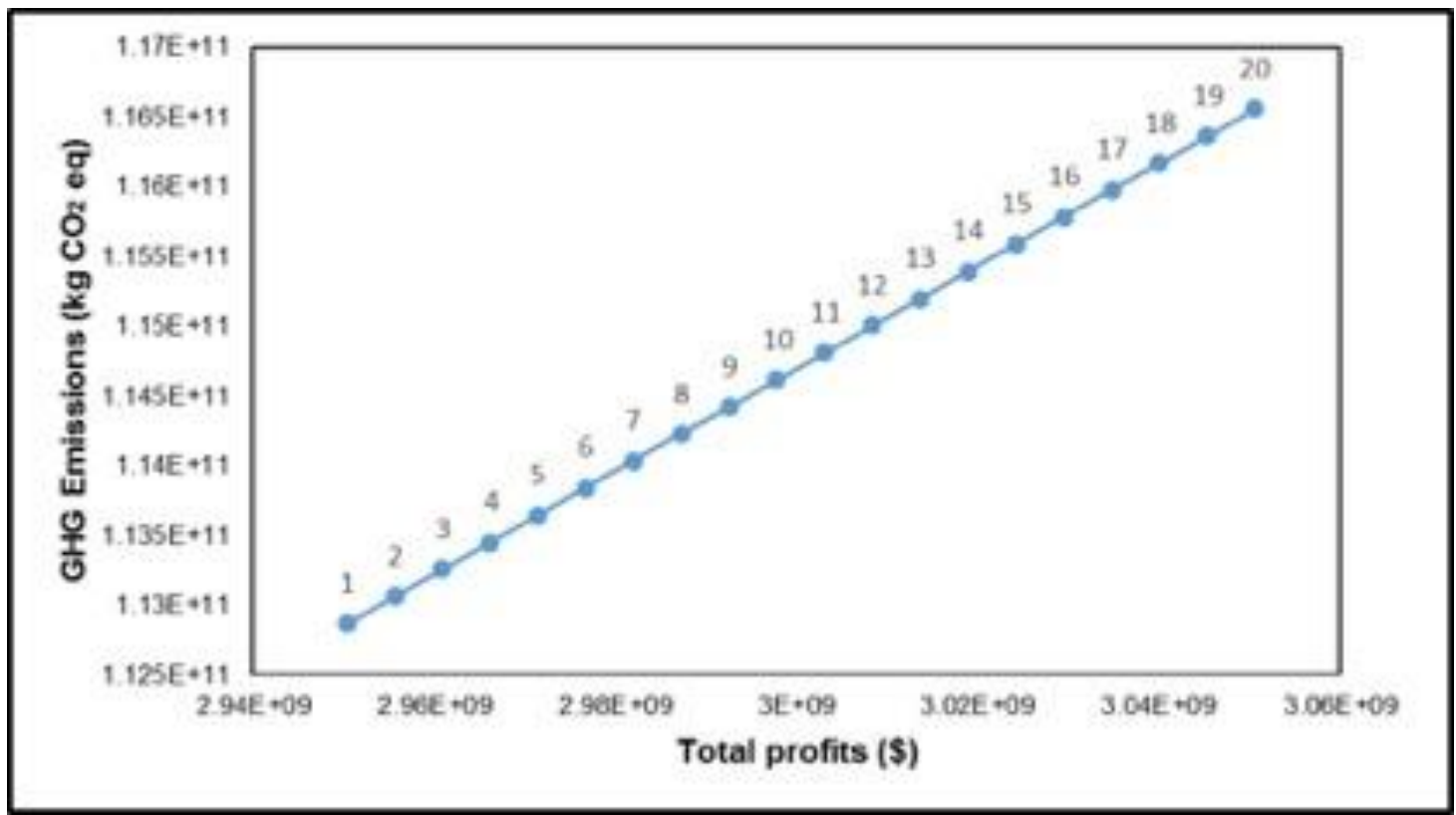

Fig. 7. Tradeoff between the total profits and GHG emissions of the supply chain for the first scenario

\section{Results for the Southeastern MO Scenario}

In the second scenario, when the production plant was located near the feedstock sources, the demands of all of the customers were fully satisfied. However, the eight nearby customers were not able to buy all of the feedstock resources. According to the results, the nearby customers were only able to buy half of the total feedstock resources. Therefore, the producer would need to explore customers further away to sell all of the large feedstock amount. According to an extra analysis, it was feasible to serve customers within $544 \mathrm{mi}$ by railcar and customers within $272 \mathrm{mi}$ by truck. Serving customers at these distances could still result in profits for the whole bio-butanol supply chain.

In this scenario, the optimal bio-butanol transportation method was also railcar. The maximum profits for five years were $\$ 3,403$ million, with total GHG emissions of 
128.995 million t of $\mathrm{CO}_{2}$ eq over five years and an annual production yield of $10,600,000$ $\mathrm{t}$ of bio-butanol. To solve the MOLP problem, the $\mathcal{E}$-constraint method was used. The relationship between the total profits and GHG emissions was also positive linear, as shown in Fig. 8. If the GHG emissions decreased by 215 thousand $\mathrm{t}$ of $\mathrm{CO}_{2}$ eq, the total profits of the bio-butanol supply chain decreased by $\$ 5.7$ million. To reduce the GHG emissions by $1 \mathrm{t}$ of $\mathrm{CO}_{2}$ eq, the producer needed to pay $\$ 26.50$.

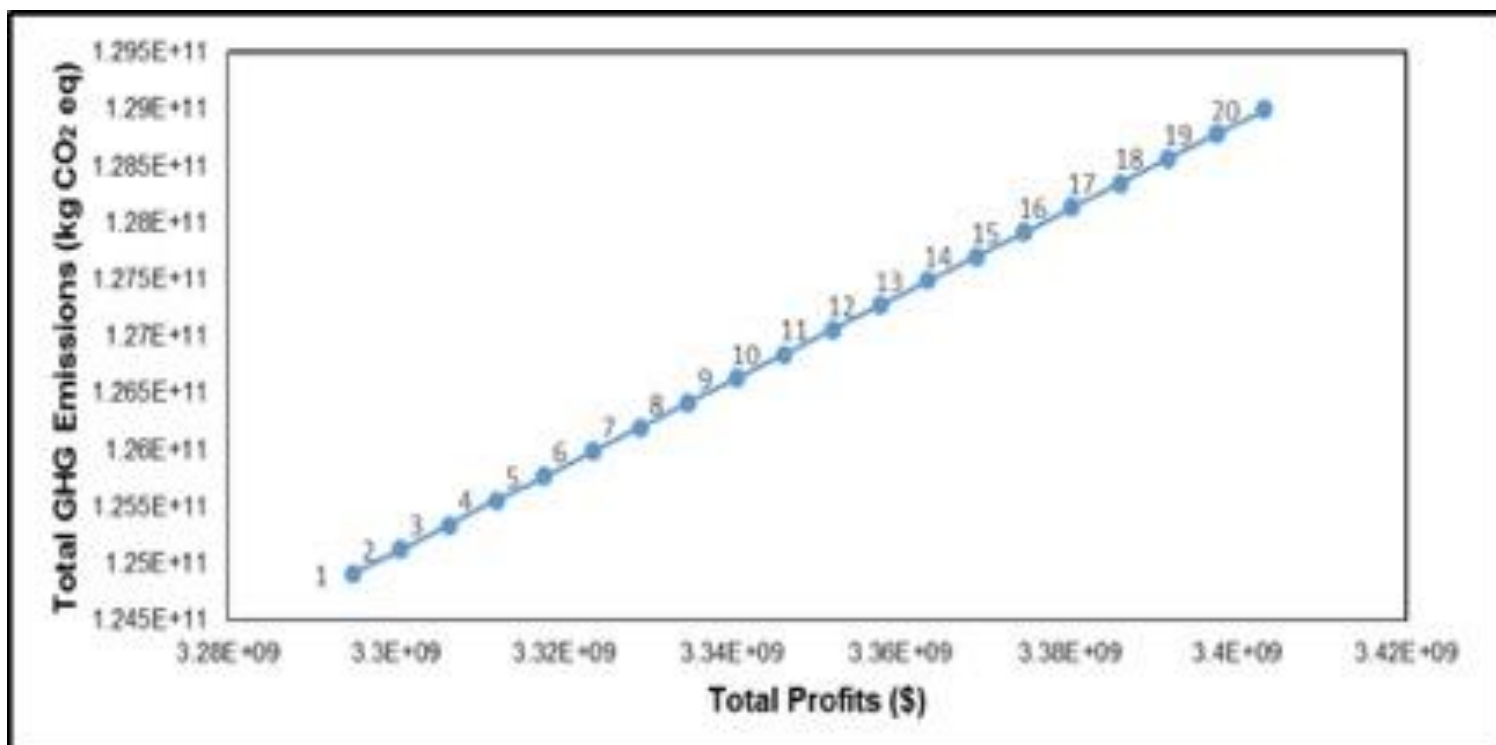

Fig. 8. Tradeoff between the total profits and GHG emissions of the supply chain for the second scenario

\section{Comparing the Results from Both Scenarios}

The supply chain in the southeastern MO scenario pays less to reduce $1 \mathrm{t}$ of $\mathrm{CO}_{2}$ eq than the producer in the central MO scenario.

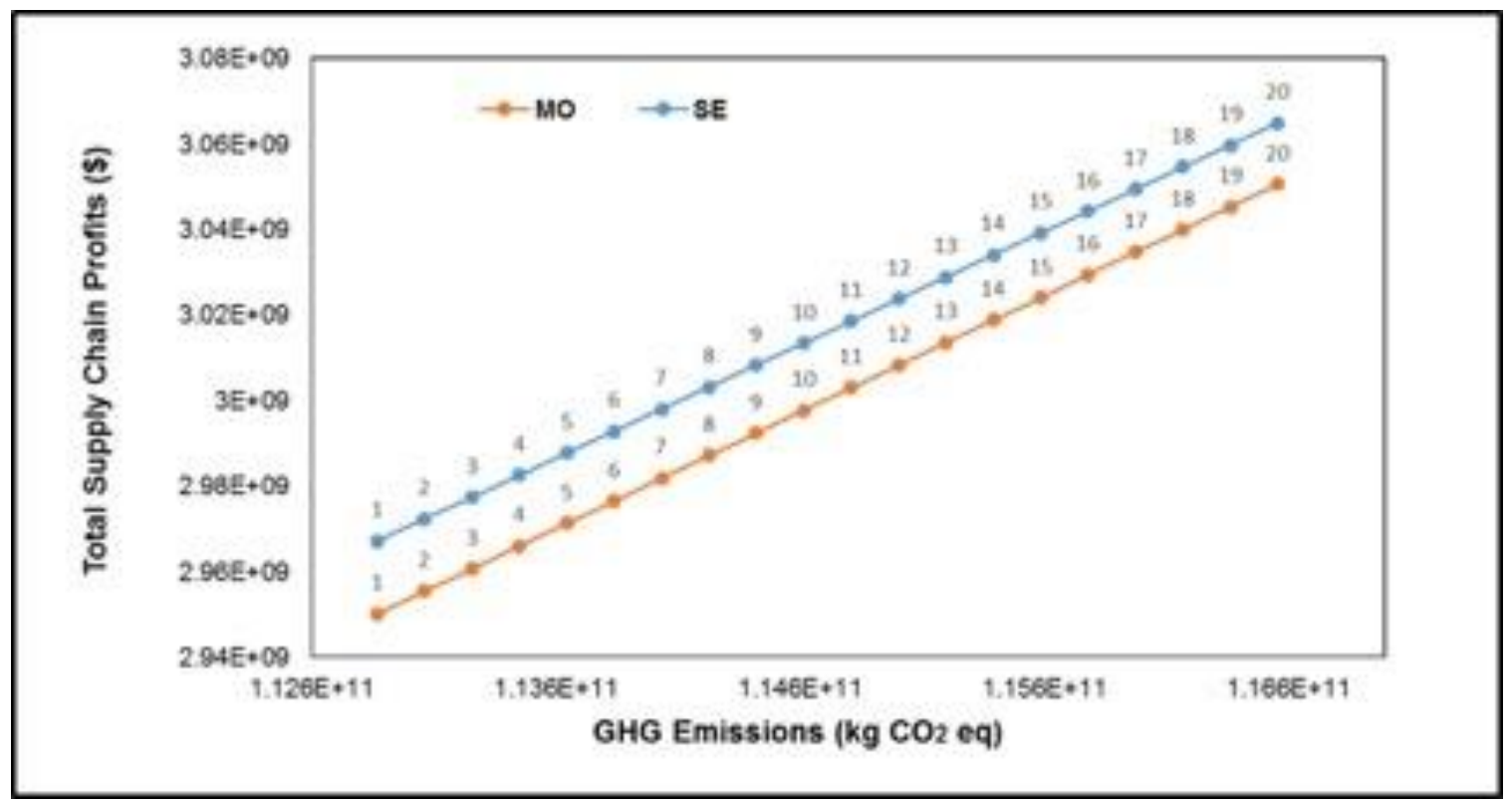

Fig. 9. Comparison of the total supply chain profits for both scenarios with the same amount of GHG emissions 
Additionally, the maximum profits for five years of the bio-butanol supply chain in southeastern $\mathrm{MO}$ was $\$ 353$ million higher than that of the central MO scenario. However, the associated GHG emissions of the southeastern MO scenario were 12.44 million $\mathrm{t}$ of $\mathrm{CO}_{2}$ eq higher than that of the central $\mathrm{MO}$ case. Therefore, to better compare both cases, an additional analysis was conducted to determine the economic differences between the two cases with the same amount of GHG emissions. The results of this analysis are shown in Fig. 9.

From Fig. 9, it was obvious that the total supply chain profits of the southeastern MO scenario were still higher than the profits of the central MO scenario, even with the same amount of GHG emissions. Therefore, the performance of the southeastern MO scenario was better than that of the central MO scenario. Under the assumptions made in this study, the feedstock availability was more important than the market availability when designing the sorghum stem bio-butanol supply chain network in MO.

\section{Determination of the Bio-Butanol Supply Chain Production Size}

According to the previous analysis, the eight nearby customers in southeastern MO were not able to utilize all of the feedstock. Because the feedstock was not exhausted, more customers were needed to buy the feedstock, which would increase the production size and total profits. A further analysis was therefore conducted to determine if having more customers could improve the performance of the supply chain network. In addition to the eight customers nearby, this analysis included six other customers from central MO. The results of this analysis are shown in Fig. 10.

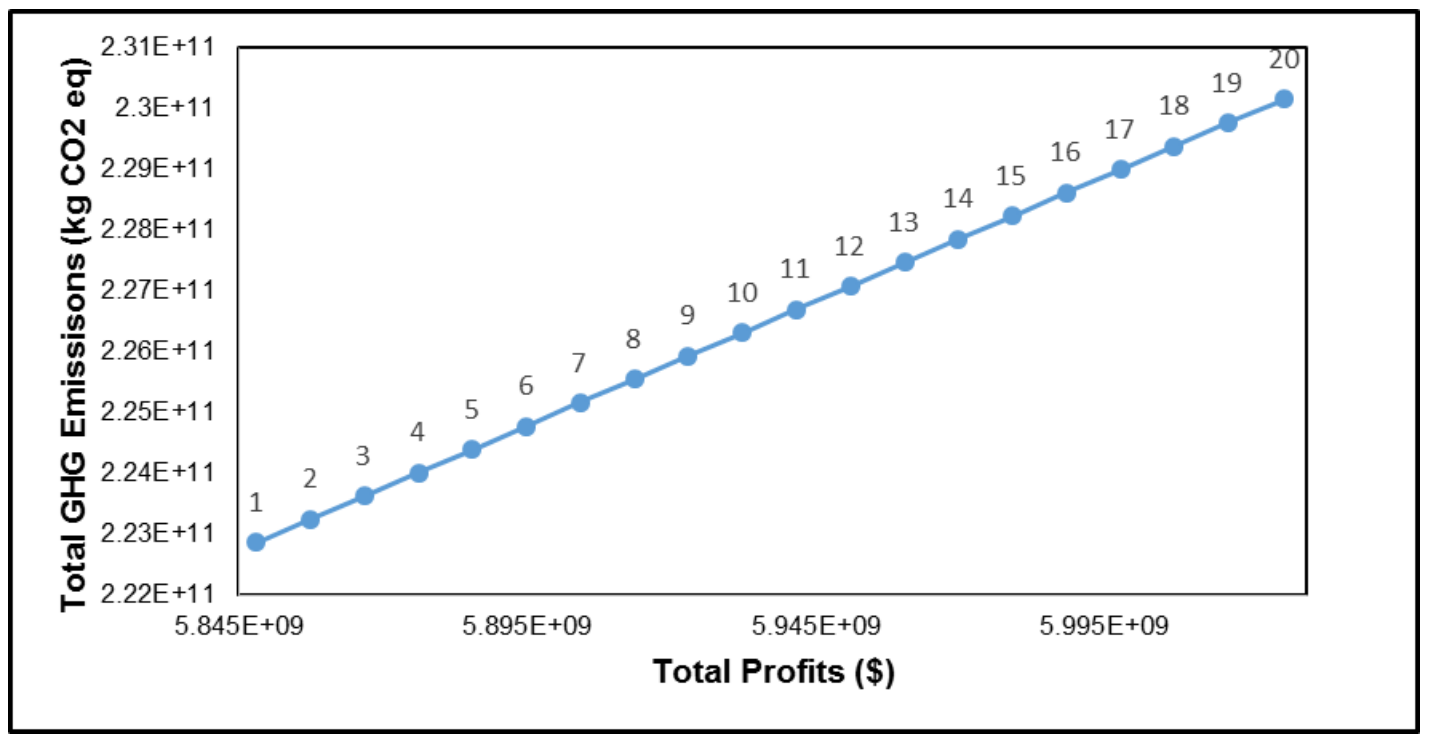

Fig. 10. Further analysis of the relationship between the total profits and GHG emissions of the supply chain for the southeastern MO scenario with an increased number of customers

From Fig. 10, the relationship between the total profits and GHG emissions was still positive-linear. To reduce the GHG emissions by $1 \mathrm{t}$ of $\mathrm{CO}_{2} \mathrm{eq}$, the producer needed to pay approximately $\$ 24.40$, which was lower than for the previous two scenarios. It is necessary to mention that the optimal bio-butanol transportation method was by railcar.

To determine the size of the bio-butanol production plant, the environmental objective needed to be considered. In this case, an extra analysis was conducted to study 
production plant sizes with different possible weights on the economic and environmental objectives. The results of this analysis are shown in Table 10.

Table 10. Production Sizes for the Different Scenarios

\begin{tabular}{|c|c|c|c|}
\hline $\begin{array}{c}\text { Economic } \\
\text { Weight }(\%)\end{array}$ & $\begin{array}{c}\text { Total Profits (million } \\
\text { dollars) }\end{array}$ & $\begin{array}{c}\text { GHG Emissions (million t of } \\
\mathrm{CO}_{2} \text { eq) }\end{array}$ & $\begin{array}{c}\text { Production Size } \\
\text { (million t) }\end{array}$ \\
\hline 100 & 6026.16 & 230.15 & 18.9 \\
\hline 95 & 5724.85 & 217.80 & 17.95 \\
\hline 90 & 5423.54 & 205.45 & 17.01 \\
\hline 85 & 5122.24 & 193.10 & 16.06 \\
\hline 80 & 4820.93 & 180.75 & 15.11 \\
\hline
\end{tabular}

\section{Sensitivity Analysis}

In order to provide more insights into the modelling results, a sensitivity analysis was conducted. In this analysis, the values of some important input parameters were changed to study the effects of these parameters into the objective functions. To illustrate how these parameters affect the optimal solutions, the values of important input parameters are changed in the range of $[-50 \%, 50 \%]$. The total supply chain profits and the GHG emissions were calculated based on the changes of each input parameters. The following figures presents the results of the sensitivity analysis.

Figures 11 and 12 indicate the changes of some costs and their effects in the total supply chain profits. The changes in sorghum stalk harvest costs and bio-butanol transportation costs caused very limited changes in the total supply chain profits. Changes of bio-butanol production costs and bio-butanol sale prices affected the total supply chain profit the most. By decreasing the bio-butanol production costs by $50 \%$, the total profits were increased to $388 \%$, while the bio-butanol supply chain was nonprofitable when increasing the production costs by more than $10 \%$. The total supply chain profits increased by $444 \%$ by increasing the bio-butanol sale price by $50 \%$, while the bio-butanol supply chain was non-profitable when decreasing the bio-butanol sale price by more than $10 \%$.

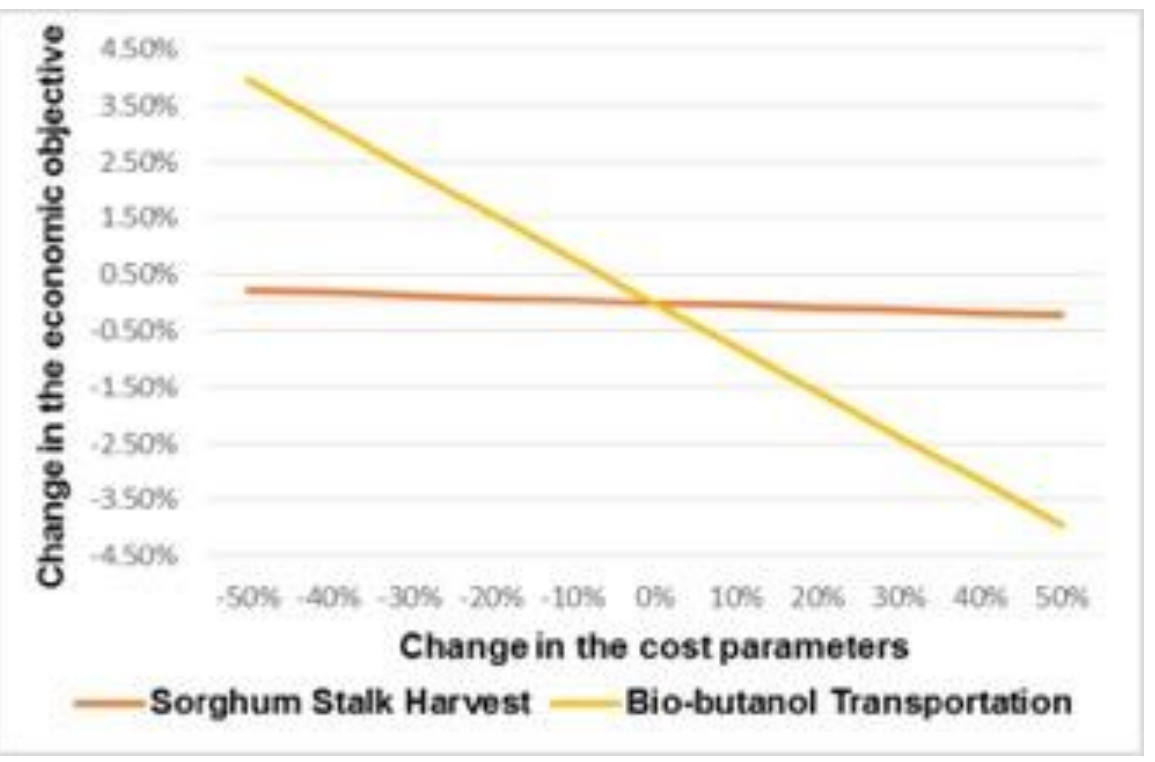

Fig. 11. The NPV against the percentage change in cost parameters 


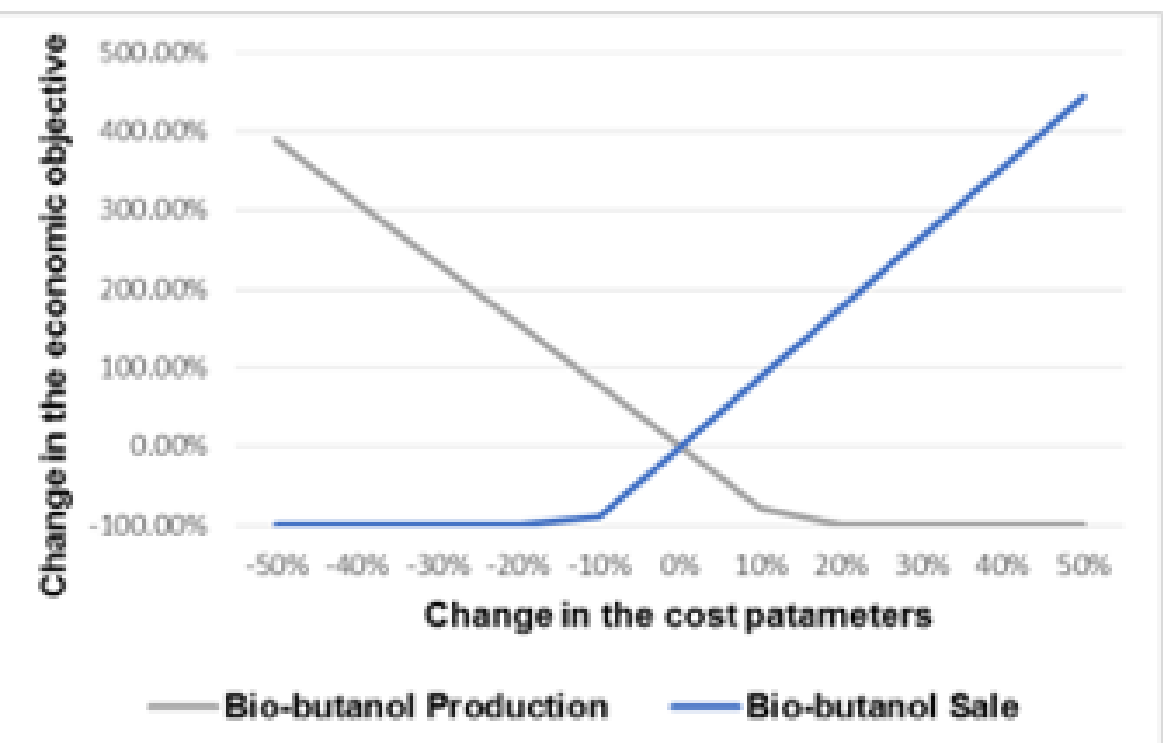

Fig. 12. The NPV against the percentage change in the production cost and biofuel sale

Figure 13 indicates the change in demand and the effects on the total supply chain profits and GHG emissions. The GHG emissions has a decreasing and linear trend as the demand decreased. Decreasing the current demand for $10 \%$ caused a $10 \%$ decrease in GHG emissions. The GHG emissions increased as the demand increased, though the effects were very limited. Increasing the demand by $10 \%$ only caused a $3.37 \%$ increase in GHG emissions. However, after increasing the current demand for more than $10 \%$, the GHG emissions began to decrease. Increasing the current demand for $10 \%$ caused a $0.01 \%$ decrease in $\mathrm{GHG}$ emissions.

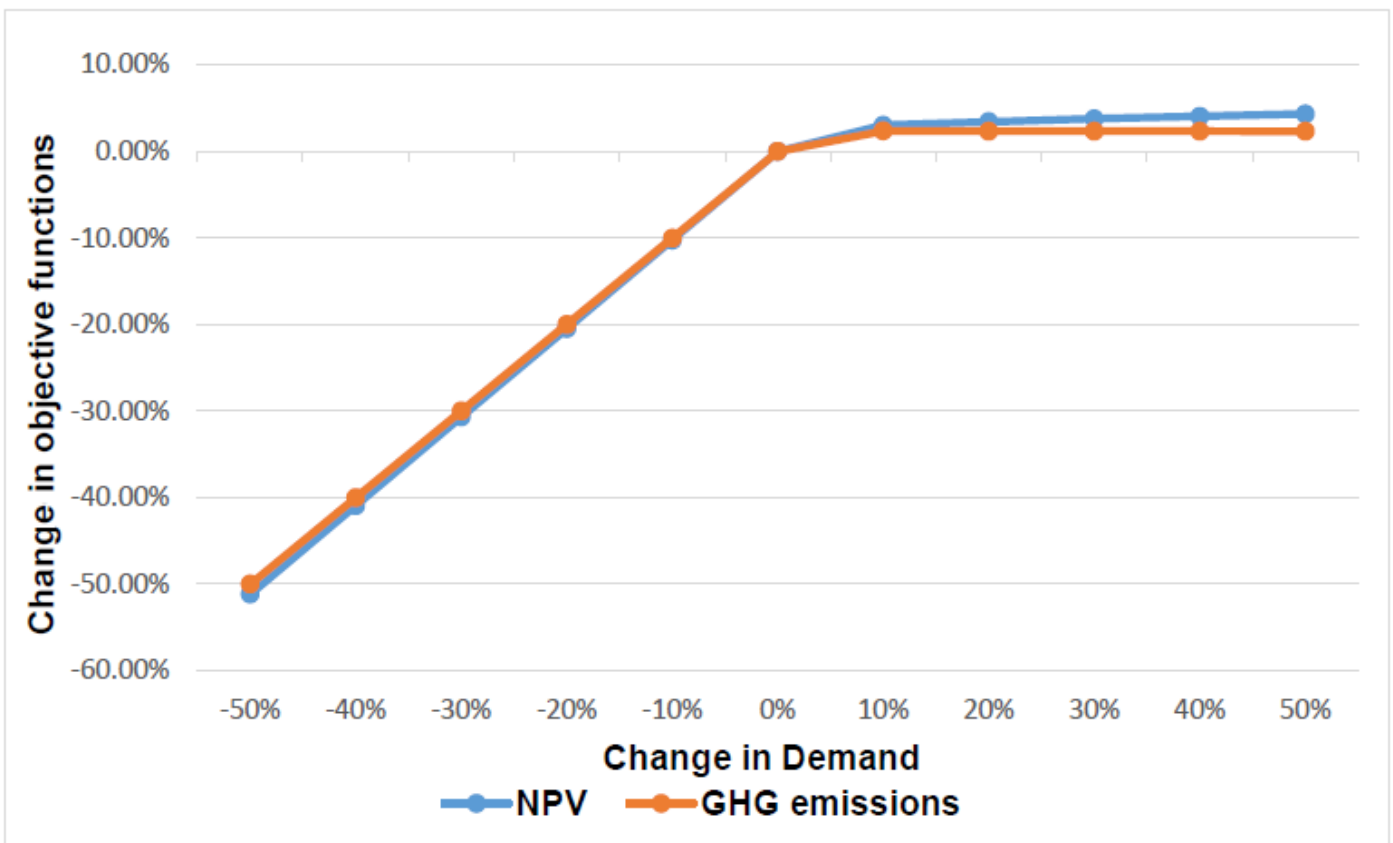

Fig. 13. The objective functions against the percentage change in demand

The total supply chain profits also had the similar changing pattern when the demand was decreased. However, the supply chain profits increased as the demand 
increased, though the changings were very limited. The supply chain profits only increased by $4.35 \%$ when the demand increased by $50 \%$. It is necessary to point out that after increasing the demand by $10 \%$, the supply chain profits increased, but the GHG emissions decreased.

\section{CONCLUSIONS}

1. Similar to other supply chain structures, it was found that the structural dimension of a bio-butanol supply chain contains four tiers of a horizontal structure: supplier, manufacturer, distributor, and customer. The bio-butanol companies are located in the middle of the horizontal structure. The vertical structure of bio-butanol supply chains varies, depending on the number and types of biomass feedstock produced and the number and types of bio-butanol purchasers.

2. A multi-objective linear programming (MOLP) model combined with a life cycle analysis (LCA) was developed to optimize the sorghum stem bio-butanol supply chain network. The model was used to determine the bio-butanol transportation method, as well as the location and size of a bio-butanol production plant by optimizing both the economic and environmental objectives.

3. After applying the MOLP model it was found that the optimal location of a cellulosic butanol production in the state of Missouri can achieve a maximum profit of $\$ 3.4$ billion, total GHG emissions of 128.9 tons of $\mathrm{CO}_{2}$ eq, and a production of 10.6 million tons of bio-butanol within five years. These results would need to be validated.

4. The model was applied in two cases in MO to deal with the tradeoff between the feedstock and market availabilities. Under the assumptions made in this study, the feedstock availability was more important than the market availability when designing a sorghum stem bio-butanol supply chain network in MO.

5. Biomass feedstock and biofuel market availability are the two primary factors for choosing the ideal location of a cellulosic bio-butanol production plant. According to the analysis of the two scenarios in MO, the optimal location for the bio-butanol production plant is in southeastern MO, where there is abundant sorghum stem resources.

6. Under the assumptions of this study, the optimal transportation method for biobutanol is railcar because of its low delivery costs and GHG emissions.

7. The production size of the bio-butanol production plant was based on the tradeoff between the economic and environmental objectives. A higher adherence to the environmental objective resulted in a smaller production plant.

\section{ACKNOWLEDGMENTS}

The authors are grateful for the support of the U.S. Department of Energy and to the Joint Clean Energy Research and Development Center (JCERD) for funding this research. 


\section{REFERENCES CITED}

Ahi, P., and Searcy, C. (2015). "An analysis of metrics used to measure performance in green and sustainable supply chains," J. Clean. Prod. 86(1), 360-377. DOI: 10.1016/j.jclepro.2014.08.005

Akgul, O., Shah, N., and Papageorgiou, L. D. (2012). "An optimisation framework for a hybrid first/second generation bioethanol supply chain," Comput. Chem. Eng. 42, 101-114. DOI: 10.1016/j.compchemeng.2012.01.012

Almodares, A., Hadi, M. R., and Ahmadpour, H. (2008). "Sorghum stem yield and soluble carbohydrates under different salinity levels," Afr. J. Biotechnol. 7(22), 40514055. DOI: $10.5897 / A J B 08.156$

Amin, S. H., and Zhang, G. (2013). "A multi-objective facility location model for closedloop supply chain network under uncertain demand and return," Appl. Math. Model. 37(6), 4165-4176. DOI: 10.1016/j.apm.2012.09.039

Autry, C., Goldsby, T., Bell, J., Moon, M., Munson, C., Watson, M., Lewis, S., Cacioppi, P., and Jayaraman, J. (2013). The Definitive Guide to Modern Supply Chain Management (Collection), Pearson Education, Upper Saddle River, NJ.

Baños, R., Manzano-Agugliaro, F., Montoya, F. G., Gil, C., Alcayde, A., and Gómez, J. (2011). "Optimization methods applied to renewable and sustainable energy: A review,” Renew. Sust. Energ. Rev. 15(4), 1753-1766. DOI:

10.1016/j.rser.2010.12.008

Cherubini, F., and Strømman, A. H. (2011). "Life cycle assessment of bioenergy systems: State of the art and future challenges," Bioresource Technol. 102(2), 437-451. DOI: 10.1016/j.biortech.2010.08.010

Comas Martí, J. M., Tancrez, J.-S., and Seifert, R. W. (2015). "Carbon footprint and responsiveness trade-offs in supply chain network design," Int. J. Prod. Econ. 166, 129-142. DOI: 10.1016/j.ijpe.2015.04.016

Corsano, G., Vecchietti, A. R., and Montagna, J. M. (2011). “Optimal design for sustainable bioethanol supply chain considering detailed plant performance model," Comput. Chem. Eng. 35(8), 1384-1398. DOI: 10.1016/j.compchemeng.2011.01.008

Dutton, J. A. (2017). "Economics of butanol production," Alternative Fuels from Biomass Sources, (https://www.e-education.psu.edu/egee439/node/721), Accessed on $8^{\text {th }}$ May 2017.

Eskandarpour, M., Dejax, P., Miemczyk, J., and Péton, O. (2015). "Sustainable supply chain network design: An optimization-oriented review," Omega 54, 11-32. DOI: 10.1016/j.omega.2015.01.006

Eskandarpour, M., Zegordi, S., and Nikbakhsh, E. (2013). “A parallel variable neighborhood search for the multi-objective sustainable post-sales network design problem," Inter. J. Prod. Econ. 145(1), 117-131. DOI: 10.1016/j.ijpe.2012.10.013

Giarola, S., Shah, N., and Bezzo, F. (2012). "A comprehensive approach to the design of ethanol supply chains including carbon trading effects," Bioresource Technol. 107, 175-185. DOI: 10.1016/j.biortech.2011.11.090

Gu, X., Huang, Z., Cai, J., Gong, J., Wu, X., and Lee, C.-f. (2012). “Emission characteristics of a spark-ignition engine fuelled with gasoline- $n$-butanol blends in combination with EGR," Fuel 93, 611-617. DOI: 10.1016/j.fuel.2011.11.040

Harraz, N. A., and Galal, N. M. (2011). "Design of sustainable end-of-life vehicle recovery network in Egypt," Ain Shams Eng. J. 2(3-4), 211-219. DOI: 10.1016/j.asej.2011.09.006 
Harris, I., Naim, M., Palmer, A., Potter, A., and Mumford, C. (2011). "Assessing the impact of cost optimization based on infrastructure modelling on $\mathrm{CO}_{2}$ emissions," Inter. J. Prod. Econ. 131(1), 313-321. DOI: 10.1016/j.ijpe.2010.03.005

ISO 14040 (2006). "Environmental management_Life cycle assessment-Principles and framework," International Organization for Standardization, Geneva, Switzerland.

Jensen, A. A., Hoffman, L., Møller, B. T., Schmidt, A., Christiansen, K., Elkington, J., and van Dijk, F. (1998). Life-cycle Assessment (LCA)—A Guide to Approaches, Experiences and Information Sources (Environmental issues series no. 6), European Environment Agency, Copenhagen, Denmark.

Kumar, P., Barrett, D. M., Delwiche, M. J., and Stroeve, P. (2009). "Methods for pretreatment of lignocellulosic biomass for efficient hydrolysis and biofuel production," Ind. Eng. Chem. Res. 48(8), 3713-3729. DOI: 10.1021/ie801542g

Kumar, M., and Gayen, K. (2011). "Developments in biobutanol production: New insights,” Appl. Energ. 88(6), 1999-2012. DOI: 10.1016/j.apenergy.2010.12.055

Lira-Barragán, L. F., Ponce-Ortega, J. M., Serna-González, M., and El-Halwagi, M. M. (2011). "An MINLP model for the optimal location of a new industrial plant with simultaneous consideration of economic and environmental criteria," Ind. Eng. Chem. Res. 50(2), 953-964. DOI: 10.1021/ie101897z

Lo Giudice, A., Mbohwa, C., Clasadonte, M. T., and Ingrao, C. (2014). "Life cycle assessment interpretation and improvement of the Sicilian artichokes production," Int. J. Environ. Res. 8(2), 305-316.

Mavrotas, G. (2009). "Effective implementation of the $\varepsilon$-constraint method in multiobjective mathematical programming problems," Appl. Math. Comput. 213(2), 455465. DOI: 10.1016/j.amc.2009.03.037

Mele, F. D., Guillén-Gosálbez, G., and Jiménez, L. (2009). “Optimal planning of supply chains for bioethanol and sugar production with economic and environmental concerns," Comp. Aid. Chem. Eng. 26, 997-1002. DOI: 10.1016/S15707946(09)70166-X

Minciardi, R., Paolucci, M., Robba, M., and Sacile, R. (2008). "Multi-objective optimization of solid waste flows: Environmentally sustainable strategies for municipalities," Waste Manage. 28(11), 2202-2212. DOI: 10.1016/j.wasman.2007.10.003

Miranda-Ackerman, M. A., Azzaro-Pantel, C., and Aguilar-Lasserre, A. A. (2017). “A green supply chain network design framework for the processed food industry: Application to the orange juice agrofood cluster," Comput. Ind. Eng. 109, 369-389. DOI: 10.1016/j.cie.2017.04.031

Mohammadi, M., Torabi, S., and Tavakkoli-Moghaddam, R. (2014). "Sustainable hub location under mixed uncertainty," Transport. Res. E-Log. 62, 89-115. DOI: 10.1016/j.tre.2013.12.005

Papapostolou, C., Kondili, E., and Kaldellis, J. K. (2011). "Development and implementation of an optimization model for biofuels supply chain," Energy 36(10), 6019-6026. DOI: 10.1016/j.energy.2011.08.013

Pishvaee, M., and Razmi, J. (2012). "Environmental supply chain network design using multi-objective fuzzy mathematical programming," Appl. Math. Model. 36(8), 34333446. DOI: 10.1016/j.apm.2011.10.007

Pourmohammadi, H., Rahimi, M., and Dessouky, M. (2008). "Sustainable reverse logistics for distribution of industrial waste/byproducts: A joint optimization of 
operation and environmental costs," Supply Chain Forum: An International Journal 9(1), 2-17. DOI: 10.1080/16258312.2008.11517186

Rebitzer, G., Ekvall, T., Frischknecht, R., Hunkeler, D., Norris, G., Rydberg, T., Schmidt, W.-P., Suh, S., Weidema, B. P., and Penningto, D. W. (2004). "Life cycle assessment: Part 1: Framework, goal and scope definition, inventory analysis, and applications," Environ. Int. 30(5), 701-720. DOI: 10.1016/j.envint.2003.11.005

Rentizelas, A. A., Tolis, A. J., and Tatsiopoulos, I. P. (2009). "Logistics issues of biomass: The storage problem and the multi-biomass supply chain," Renew. Sust. Energ. Rev. 13(4), 887-894. DOI: 10.1016/j.rser.2008.01.003

Searcy, E., Flynn, P., Ghafoori, E., and Kumar, A. (2007). "The relative cost of biomass energy transport," Appl. Biochem. Biotech. 137-140(1-12), 639-652. DOI: 10.1007/s12010-007-9085-8.

Sharma, B., Ingalls, R. G., Jones, C. L., and Khanchi, A. (2013). "Biomass supply chain design and analysis: Basis, overview, modeling, challenges, and future," Renew. Sust. Energ. Rev. 24, 608-627. DOI: 10.1016/j.rser.2013.03.049

Srivastava, S. K. (2007). "Green supply-chain management: A state-of-the-art literature review,” Int. J. Manag. Rev. 9(1), 53-80. DOI: 10.1111/j.1468-2370.2007.00202.x

The World Bank (2011). "Railway costs and cost of alternatives," (https://ppiaf.org/sites/ppiaf.org/files/documents/toolkits/railways_toolkit/ch1_1_4.ht $\mathrm{ml})$, Accessed on $8^{\text {th }}$ May 2017.

U.S. EPA (2010). "Renewable fuel standard program (RFS2) regulatory impact analysis," U.S. Environmental Protection Agency, (http://nepis.epa.gov/Exe/ZyPURL.cgi?Dockey=P1006DXP.txt), Accessed on $3^{\text {rd }}$ August 2016.

USDA (2015a). "Sorghum area planted and harvested, yield, and production by county Missouri: 2014," U.S. Department of Agriculture, (https://www.nass.usda.gov/Statistics_by_State/Missouri/Publications/County_Estim ates/2014/Sorghum_Production_by_County.pdf), Accessed on $3^{\text {rd }}$ May 2017

USDA (2015b). "Sorghum area planted and harvested, yield, and production by county Missouri: 2015," U.S. Department of Agriculture, (https://www.nass.usda.gov/Statistics_by_State/Missouri/Publications/Annual_Statist ical_Bulletin/2015/2015-MO_Annual_Bulletin_Sorghum_ce.pdf). Accessed on $3^{\text {rd }}$ May 2017

Wright, L. A., Kemp, S., and Williams, I. (2011). "Carbon footprinting: Towards a universally accepted definition," Carbon Manag. 2(1), 61-72. DOI: $10.4155 / \mathrm{cmt} .10 .39$

Yeh, W.-C., and Chuang, M.-C. (2011). "Using multi-objective genetic algorithm for partner selection in green supply chain problems," Expert Syst. Appl. 38(4), 42444253. DOI: 10.1016/j.eswa.2010.09.091

You, F., Tao, L., Graziano, D., and Snyder, S. (2012). “Optimal design of sustainable cellulosic biofuel supply chains: Multiobjective optimization coupled with life cycle assessment and input-output analysis," Am. Inst. Chem. Eng. J. 58(4), 1157-1180. DOI: 10.1002/aic.12637

You, F., and Wang, B. (2011). "Life cycle optimization of biomass-to-liquid supply chains with distributed centralized processing networks," Ind. Eng. Chem. Res. 50(17), 10102-10127. DOI: 10.1021/ie200850t 
Yu, H., and Solvang, W. D. (2016). "An improved multi-objective programming with augmented $\varepsilon$-constraint method for hazardous waste location-routing problems," Int. J. Environ. Res. Pub. Health 13(6), 548-569. DOI: 10.3390/ijerph13060548

Yue, D., Slivinsky, M., Sumpter, J., and You, F. (2014). "Sustainable design and operation of cellulosic bioelectricity supply chain networks with life cycle economic, environmental, and social optimization," Ind. Eng. Chem. Res. 53(10), 4008-4029. DOI: $10.1021 / \mathrm{ie} 403882 \mathrm{v}$

Zhang, T., Du, N., and Tan, T. (2011). "Biobutanol production from sweet sorghum bagasse,” J. Biobased Mater. Bioenerg. 5(3), 331-336. DOI: 10.1166/jbmb.2011.1158

Zhang, D., Zou, F., Li, S., and Zhou, L. (2017). "Green Supply Chain Network Design with Economies of Scale and Environmental Concerns," J. Adv. Transport. 2017. DOI: $10.1155 / 2017 / 6350562$

Article submitted: July 12, 2017; Peer review completed: November 11, 2017; Revised version received and accepted: May 25, 2018; Published: June 6, 2018.

DOI: 10.15376/biores.13.3.5617-5642 